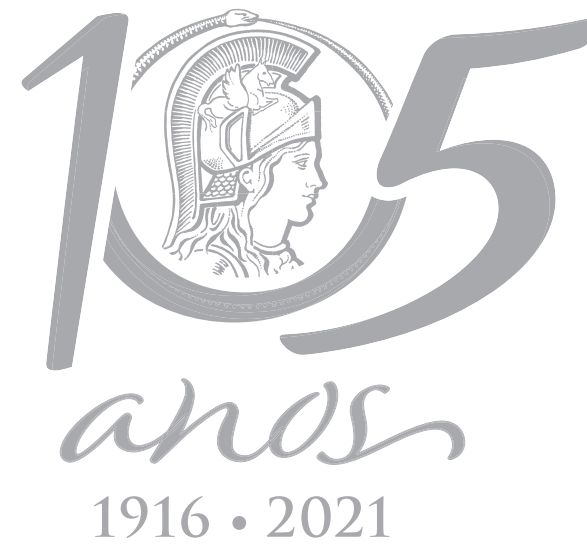

$1916 \cdot 2021$

\title{
Free Radicals and Actinobacteria as a Misexplored Goldmine of Antioxidant Compounds
}

\author{
THALES HENRIQUE B. DE OLIVEIRA, NORMA B. DE GUSMÃO, LEONOR A.O. DA \\ SILVA, LUANA C.B.B. COELHO
}

\begin{abstract}
Free radicals are highly reactive unstable molecules, which can be synthesized in different ways, considered harmful and threatening to humans; these chemical species have free traffic throughout the human body, interacting with biological molecules and human body organ tissues. The interaction between free radicals and biological molecules is the main factor for disease development or pre-existing disease symptoms aggravation. Antioxidants are chemical compounds able to donate electric charge to stabilize molecules such as free radicals. Recent studies have proved the benefits of antioxidants intake in health improvement. In this way, the search for natural sources of antioxidants has become an ascending trend. In this field, the microbial sources are considered poorly explored compared to the numerous amount of other compounds obtained from them, especially from Actinobacteria. The searched literature about Actinobacteria highlights an important capacity of producing natural antioxidants; however, there is a lack of in vivo studies of these isolated compounds. In this review, we gathered information that supports our point of view that Actinobacteria is a truly renewable and superficially explored source of natural antioxidants. Furthermore, our purpose is also to point this limitation and stimulate more researches in this area.
\end{abstract}

Key words: Free radicals, antioxidants, oxidative stress, Actinobacteria antioxidant.

\section{INTRODUCTION}

Free radicals are dangerous molecules to cells and the human body. The excess of these molecules causes tissue damage and disease development or worsening. The free diffusion of free radicals throughout the body and the malfunction of antioxidant enzyme systems are concomitant factors that contribute severely to reactivity with cell biomolecules. In a first approach, it was established that free radicals formation was restricted to aerobic metabolism, but actually, transition metals, organelles, and other enzymes can also synthesize free radicals. Some additional factors are involved in free radical syntheses such as xenobiotics, intake of industrial synthetic compounds, and lifestyle.

Antioxidants are molecules that stabilize free radicals donating protons or electrons. They can be a result of a chemically synthetic process or a natural metabolite. Thus, antioxidants are able to mitigate deleterious effects caused by free radicals and protecting the cells and tissues against damages, stopping free radical forming chain reactions, scavenging formed radicals, regenerating damaged structures, or reinforcing cell defendant systems. Lately, the search for natural products has increased; in the same way, the exploration for natural antioxidants 
has gained attention being directed to plant exploration, mostly.

Actinobacteria is a renewable source of natural bioactive molecules. This group of bacteria is a true reservoir of antimicrobial, antifungal, antitumor, and immunomodulator compounds. Even though, up to this time, there is no mention of any approved Actinobacteria compound with known antioxidant activity for human use. Then, it makes sense to hook up this absence and the emergent exploration of Actinobacteria toward antioxidant approach with some other factors, such as low or non-toxicity of Actinobacteria compounds in counterpart to synthetic antioxidants as described in the following issues.

This review focused on the antioxidant potential of molecules produced by Actinobacteria isolated from different environments and its potential of extinguishment of the most variety of unstable molecules, with many unknown and non-reported compounds as an escape route to this trouble. Data from the literature have demonstrated the quenching of some unpaired molecules such as hydrogen peroxide and cationic radicals by 2,6-dimethoxy terephthalicacidand1-hydroxy-nonrresistomicin as well as cell redox balance maintenance by angeloline $A$ and actinosporines $C$ and $D$ all of them produced by Actinobacteria. Therefore, supported by these findings our purpose is also to show the potential of antioxidant compounds from Actinobacteria for human usage despite some evident limitations in this field.

\section{FREE RADICALS}

\section{Origin, action on macromolecules and cell metabolism}

Free radicals are widely defined as molecules or atoms with a characteristic imparity of at least one electron in the last atomic orbital. Free radicals are mainly derived from reactions involving molecular oxygen or nitrogen being grouped as Reactive Oxygen or Nitrogen Species (ROS and RNS) (Table I). These chemical species may be negatively or positively charged, have a short half-life and its electric disparity is the main factor to high reactivity with biological molecules in the origin site or outside via secondary mediators cascade (Nikki 2010).

Free radicals are mainly formed through oxidoreduction reactions by electron addition

Table I. Reactive oxygen species and reactive nitrogen species.

\begin{tabular}{|c|c|c|}
\hline \multirow{4}{*}{$\begin{array}{c}* \\
\text { Reactive Oxygen Species } \\
\text { (ROS) }\end{array}$} & Radical & Non-Radical \\
\cline { 2 - 3 } & Superoxide $\left(\mathrm{O}_{2}^{-}\right)$ & Hydrogen peroxide $\left(\mathrm{H}_{2} \mathrm{O}_{2}\right)$ \\
\cline { 2 - 3 } & Hydroxyl $(\mathrm{OH})$ & Singlet oxygen $\left(\mathrm{O}_{2}\right)$ \\
\cline { 2 - 3 } & Peroxyl $\left(\mathrm{RO}_{2}^{-}\right)$ & Hypochlorous acid $(\mathrm{HClo})$ \\
\cline { 2 - 3 } & Alkoxyl $\left(\mathrm{RO}^{-}\right)$ & Ozone $\left(\mathrm{O}_{3}\right)$ \\
\cline { 2 - 3 } & & Hypobromous acid $(\mathrm{Hbro})$ \\
\hline \multirow{3}{*}{$\begin{array}{c}\text { Reactive Nitrogen Species } \\
\text { (RNS) }\end{array}$} & Radical & Non-Radical \\
\cline { 2 - 3 } & Nitric oxide $\left(\mathrm{NO}^{-}\right)$ & Peroxynitrite $\left(\mathrm{ONOO}^{-}\right)$ \\
\cline { 2 - 3 } & Nitrogen dioxide $\left(\mathrm{NO}_{2}\right)$ & Nitrosyl cation $\left(\mathrm{NO}^{+}\right)$ \\
\cline { 2 - 3 } & & Nitrogen trionion $\left(\mathrm{NO}^{-}\right)$ \\
\cline { 2 - 3 } & & Nitrogen tetraoxide $\left(\mathrm{NO}_{3}\right)$ \\
\hline & & Nitrous acid $\left(\mathrm{NNO}_{2}\right)$ \\
\hline
\end{tabular}

Based on Phaniendra (2015). 
or removal and can exist without binders or carriers. The aerobic metabolism (Reaction I) is the main source of ROS being the mitochondria the protagonist of electron transference reactions through oxidative phosphorylation in the electron transport chain. As described by Mourier \& Larsson (2011), complex I (NADH ubiquinone oxidoreductase) and complex III (cytochrome bc1) are the main generators of reactive oxygen species.

Some other non-enzymatic reactions such as those involving transition metal ions can also lead to ROS and RNS formation. Fenton reactions (Reactions II - III) describe the interaction between ferrous $\left(\mathrm{Fe}^{2+}\right)$ or ferric iron $\left(\mathrm{Fe}^{3+}\right)$ and hydrogen peroxide $\left(\mathrm{H}_{2} \mathrm{O}_{2}\right)$ forming hydroxyl $(\mathrm{OH})$ and hydroperoxyl $\left(\mathrm{HO}_{2}^{-}\right)$radicals (Propac et al. 2017). The propagation of the Fenton Reaction is headed by the Haber-Weiss reaction (Reaction IV) which catalyzes the reduction of ferric iron to ferrous iron through mitochondrial superoxide ion $\left(\mathrm{O}_{2}^{-}\right)$interaction, leading to a free radical formation looping by Fenton reaction.

ROS overproduction is the main factor for oxidative stress, which leads to diseases development or aggravation by tissue oxidative damage. Regardless of the interaction with transition metals to form RNS, the synthesis of nitric oxide (NO) and peroxynitrite (ONOO-) (Reaction V) through L-arginine decomposition by oxide nitric synthase is also reported (Fionda et al. 2016). RNS display a crucial role as antimicrobial agents, immunological modulators, vascular function regulators, and signaling molecules (Adams et al. 2015). However, the excess of RNS generation is noxious to the body in order to nitrosative stress triggering.

Notwithstanding, the mitochondria as the main source of reactive species, other cytoplasmic organelles as peroxisomes (Tripathi \& Walker 2016), endoplasmic reticulum (Wang \& Kaufman 2016), and lysosomes (Fu et al. 2015) have been reported as free radical producers. Enzymes as cell membrane NADPH-oxidases (NOx) (Kovac et al. 2015), cytochrome P450 oxidase (CyP450) (Brown \& Borutaite 2012), superoxide dismutase (SOD) (Nguyen et al. 2020), and nitric oxide synthases (eNOS) (Brown \& Borutaite 2012) are also reported as reactive species sources (Figure 1).

Exogenous factors as xenobiotics are described as strong inducers of ROS synthesis (Żukowski et al. 2018). The metabolization of alcohol by cytochrome $\mathrm{P} 450$ oxidase yields ROS as a process byproduct (Li et al. 2016). Likewise, polycyclic hydrocarbons derivatives generate ROS by electron transfer to molecular oxygen through UV absorption and quinine metabolization (Yang et al. 2017a). The air pollutant ozone $\left(\mathrm{O}_{3}\right)$ is also pointed out as a dangerous ROS to cells (Aulakh et al. 2020).

Reaction I: $\mathrm{O}_{2}+\mathrm{e}^{-} \mathrm{O}_{2}$

Reaction II: $\mathrm{Fe}^{2+}+\mathrm{H}_{2} \mathrm{O}_{2}: \mathrm{Fe}^{3+}+\mathrm{OH}$

Reaction III: $\mathrm{Fe}^{3+}+\mathrm{H}_{2} \mathrm{O}_{2}: \mathrm{Fe}^{2+}+\mathrm{OOH}^{-}+\mathrm{H}^{+}$

Reaction IV: $\mathrm{Fe}^{3+}+\mathrm{O}_{2}^{-}: \mathrm{Fe}^{2+}+\mathrm{O}_{2}$

Reaction V: $\mathrm{NO}+\mathrm{O}_{2}^{-}$: $\mathrm{ONOO}^{-}$

Biological molecules are attacked at side chains releasing protons and electrons to stabilize reactive species. Fatty acids are the most prone biological molecules to oxidative damage followed by enzymes, proteins, amino acids, and nucleic acids. Lipid peroxidation is considered a threatening to cell membrane integrity as well as lipid hydroperoxides ( $\mathrm{LOOH})$ are dangerous to other macromolecules such as proteins (Zhang et al. 2018a). Among damages are fragmentations or inactivation via protein side-chain or polypeptide backbone attack, moreover post-translational modifications as nitrosylation and glutathionylation are also described (Martínez \& Andriantsitohaina 2009, Huang et al. 2016). Many studies have announced the free radicals as mediators of DNA damage and repair response system. They may change 


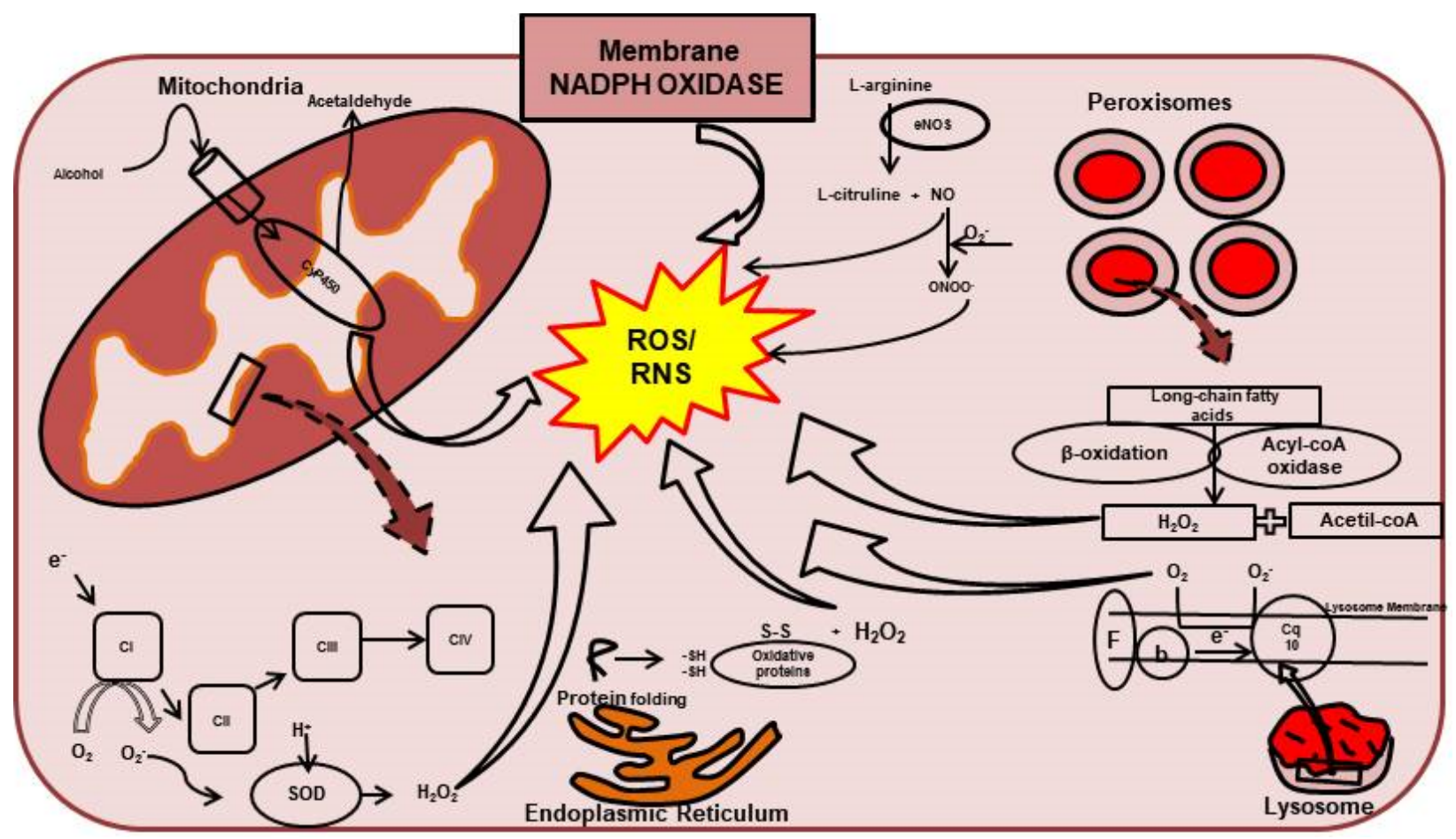

Figure 1. Schematic representation of ROS and RNS production by cell organelles and cell enzymes.

DNA structure by sugar backbone oxidation and nucleoside bases translocation (Srinivas et al. 2019).

The published literature has established free radicals' importance on cellular metabolism processes when under physiological concentrations. ROS and RNS are reported as cellular proliferation regulators (Diebold \& Chandel 2016), mediators of necrosis induction (Qin et al. 2015), genic expression modulators (Furukawa et al 2004), NFk $\beta$ activators (Topal et al. 2017), autophagy and apoptosis modulators (Redza-Dutordoir \& Averill-Bates 2016), MAPkinases activators (Henkler et al. 2010), and mediators of cellular inflammatory responses (Khojah et al. 2016).

\section{FREE RADICALS AND DISEASE PATHOPHYSIOLOGY}

Free radicals have a bifold role in a disease context. In the same way that triggers it can also participate in disease pathophysiology. In this sense, it is still established that antioxidant system imbalance and free radical damage are cofactors for disease development. Currently, approaches for oxidative stress mitigation have demonstrated being an interesting therapeutic target for disease treatment. Based on this, in this section, we gathered recent shreds of evidence about how free radicals interact or prompt diseases in the main human body organs.

\section{Nervous system diseases}

The co-participation of free radicals on nervous system pathologies is studied since the end of the last century. The high oxygen intake makes the brain tissue extremely vulnerable to oxidative damage. This condition becomes an open door to the development of neurodegenerative, and other nervous system diseases (Driver et al. 2000). The brain oxygen metabolization is the responsibility of NOx family enzymes resulting in 
ROS as a process product, which combined with other inherent conditions of nervous system pathologies, contributes to a constant synthesis of free radicals and consequent aggravation of some nervous disease symptoms (Nayernia et al. 2014).

Parkinson's disease is mainly characterized by nigra substance cells' death and dopaminergic neuron loss as a result of ROS action which leads to continuous movement and cognitive losses (Guo et al. 2018a). The ROS also might aggravate chronic cerebral inflammation through inflammasome NLRP3 lineage recruitment by pannexin and connexin hemichannels interaction (Ahmadian et al. 2019). Oxidative stress is proposed as a contributing factor behind fundamental mechanisms of neuronal loss, cell death, and dopamine levels disturbances through oxidation by ROS (Goel \& Chaudhary 2020).

Alzheimer's disease has striking characteristics such as cognitive impairment, memory losses, delusions, and mental embarrassment. Other hallmarks are synapse degeneration, hippocampus neuron death, b-amyloid deposition, and cerebral atrophy. The oxidation scenery in Alzheimer's disease is sustained by a combination of metallic ions, amyloidal aggregates, and mitochondrial dysfunction (Cheignon et al. 2018). Oxidative stress is closely linked to neuronal membrane integrity destruction. Even so, brain oxidative imbalance can also favor neurofibrillary tangle formation and increase nucleic oxidation in response to Tau protein conformation change (Wang et al. 2020).

\section{Liver diseases}

The liver is one of the body's detoxification centers being also coadjutant on metabolism balance regulation. Due to the susceptibility of hepatic tissue, reactive species attack is harmful and is also involved in physiopathology of hepatic diseases, however, in some of them, the underlying mechanisms are still not clarified (Kim et al. 2018, Liu et al. 2020). In hepatic steatosis, for example, some evidence in the literature points to a central role of mitochondrial dysfunction in liver steatosis, even with some studies highlighting the malfunction of the electron transport chain and oxidative phosphorylation. For instance, they associated the participation of NADPH oxidase with liver diseases, mainly because of the generation of anion superoxide $\left(\mathrm{O}_{2}{ }^{-}\right)$(García-Ruiz \& Fernandéz-Checa 2018).

Within the hepatic environment, the free radicals when excessively present may act as signaling molecules driving upper regulation of collagen deposition genes such as TGF- $\beta 1$ fibrogenic factor in hepatic fibrosis scenario (Tian et al. 2018), stimulating chronic hepatic inflammation through $\mathrm{Hbx}$ protein ( $\mathrm{Ha}$ \& Yu 2010), inducing lipid peroxidation that leads to hepatic tissue damage (Thuy le et al. 2017), and lipid deposition on non-alcoholic steatosis once the occurrence of mitochondrial imbalance (Marseglia et al. 2014). On the other side, the metabolization of acetaminophen by cytochrome P450 oxidase yields $\mathrm{N}$-acetyl-pbenzoquinoneimine which disturbs oxidative balance leading to cellular apoptosis of hepatocytes, centrilobular necrosis, and free radicals generation enhancement ( $\mathrm{Hu}$ et al. 2018).

It is also important to look at the other remarkable factors involved in the physiopathology of free radicals in liver diseases; within this group is alcohol. It was observed that alcohol is determinant to acute hepatic failure and alcoholic hepatic steatosis development once alcohol metabolization byproducts induce lipid peroxidation and free radicals synthesis in the liver contributing to death of hepatocytes, mainly (Wang et al. 2018). Summarily, in spite of 
the real scenario of a poorly studied physiology of free radicals within liver diseases mentioned at the top of this issue, some pieces of evidence proving the involvement of these species on liver pathologies have raised the proposal of mesenchymal stem cell therapy which is considered a promising strategy in acute liver injury treatment, as well as antioxidant therapy, pointed out as a possible, hopeful and less costly approach that has attracted attention in recent years (Hwang et al. 2019).

\section{Metabolic disorders}

Metabolic disorders such as diabetes might have ROS and RNS interaction. Diabetes is a disease characterized by insulin production dysfunction or insulin resistance that led to a raise in blood glucose levels. The glucose autoxidation on constant hyperglycemia causes superoxide radical $\left(\mathrm{O}_{2}^{-}\right)$and hydrogen peroxide $\left(\mathrm{H}_{2} \mathrm{O}_{2}\right)$ generation that mediates $b$-pancreatic cell autoimmune attack and negative regulation of cellular antioxidant systems aggravating disease symptoms (Newsholme et al. 2016). Some complications of diabetes may have symptoms aggravated by ROS and RNS. In diabetic retinopathy, for example, there is a positive correlation between ROS and retinopathy events such as the increase of vascular permeability, retinal cell apoptosis and death, and retinal vascular thickness reduction by NO removal (Lu et al. 2018). In addition, a recent work observed that REDD1 protein is the regulator of the feedback loop responsible for retinal damage mediated by ROS and visual dysfunction development in retinopathy (Miller et al. 2019).

The published literature evidence that $70 \%$ of deaths in diabetes are due to angiopathy. A study using endothelial cell culture observed that cells cultured with high glucose presented ROS accumulation as a necessary factor in diabetic angiopathy development (Xu et al. 2019a). Similarly, it was found downregulation of synthase nitric oxide enzymes in diabetic aortas might be the mechanism of vessel dysfunction on diabetic angiopathy (Liu et al. 2017). ROS are still reported as important supporters in persistent inflammation on post fractured bone healing by NLRP3 inflammasomes recruitment (An et al. 2019), moreover, ROS are involved in osteoclasts differentiation by RANKL/ RANK/OPG route expression and osteoclasts efferocytosis inhibition favoring osteoporosis in a diabetes context (Hendrijantini et al. 2019). It is of interest to report that other diabetes related-diseases such as obesity also might be influenced by reactive species. Several studies in this field support ROS role on adipose tissue characteristic inflammation as a response to NLRP3 inflammasome lineage recruitment by NADPH oxidase overregulated ROS production and caspase-1 activation route (Engin 2017). A study carried out by Sindhu et al. (2018) reported that ROS could mediate overexpression of TRL10 inflammation marker in obesity of Type-2 diabetes patients.

\section{Pulmonary diseases}

There are a few recent pieces of evidence about ROS involvement in pulmonary diseases. In allergic asthma and rhinitis, the determinant role of ROS is on the inflammation process by interleukin gene expression, as well as mucus hypersecretion, airflow restrainment due to smooth muscle contraction, bronchial hyperresponsiveness, and oxidative damage to the accessory structures of epithelial cells like cilium (Shi et al. 2018, Wang et al. 2019). ROS can also damage alveolar-capillary barrier tightjunctions proteins contributing to pulmonary edema and acute lung injury progression and development (Sokolowska et al. 2019). Moreover, extravascular liquid in the lungs has been 
pointed out as an important condition of acute respiratory distress syndrome (ARDS) where ROS contributes to interstitial liquid accumulation by epithelium (Kellner et al. 2017).

A study investigated the action of bleomycininduced oxidative stress on pulmonary fibrosis by induction of differentiation from pericytes to myofibroblasts (Andersson-Sjöland et al. 2015). In addition, other recent studies (Zhou et al. 2018, Yang et al. 2017b) also demonstrated that ROS mediated: increased inflammatory response, various degrees of edema, and hydroxyproline increase due to characteristic collagen deposition on pulmonary fibrosis. Environmental studies observed the dangerousness of photochemical generated ozone to the pulmonary environment. Ozone causes airway cell damage and disturbs gas exchange in alveoli triggering emphysema development and progression by alveoli destruction (Xu et al. 2019b).

\section{Cardiac diseases}

The high consumption of oxygen by cardiomyocytes and upper regulation of NOX family enzymes contribute to cardiac damage and heart dysfunction by ROS intoxication (Panth et al. 2016). The involvement of ROS in cardiac diseases is mainly associated with those triggered by ischemia-reperfusion (Turillazzi et al. 2017). A study using aged rats has proved that occur an imbalance in mitochondrial potential and proton gradient that leads to high production of ROS, after ischemic injury (Rancan et al. 2018). It is also believed that ROS and RNS interact with non-selective MPTP (Mitochondrial Permeability Transition Pore) pore opening that leads to molecules influx and irreversible damage to heart tissue (Cadenas 2018).

A study using isoprenaline hydrochloride as a heart failure inducer proposes MPTP pore opening by ROS as a contributive mechanism of cardiac damage aggravation (Odinokova et al.
2018). In relation to reactive species' action on vascular conditions they may cause endothelial dysfunction by NO removal, vessel smooth muscle hypertrophy, collagen production, and fibronectin deposition stimulation favoring arterial hypertension development and aggravation (Pinheiro \& Oliveira-Paula 2019). In addition, experiments with animal models have associated alcohol with endothelial NO removal and hooked up to artery resistance and endothelial inflammatory cytokines recruitment (Simplicio et al. 2016).

As well as in other tissues, in cardiac muscle inflammation, ROS participation on NLRP3 inflammasome recruitment, interleukin secretion, and NF-k $\beta$ route activation is reported (Guo et al. 2018b, Zhang et al. 2018b). However, there is not paramount evidence on acute heart failure mediated by ROS, there is a slight relationship with acute heart failure diseases as myocardial infarction, for example (Yan et al. 2019). A study using guinea-pig hearts reported an elevation of non-designated ROS in cardiomyocyte tissue (Dey et al. 2018). Moreover, it was demonstrated that oxidative stress via the calmodulin-kinase protein II-dependent route contributes to acute cardiac failure atrial fibrillation (Yoo et al. 2018).

\section{ANTIOXIDANTS: ORIGINS, CHEMISTRY OF ACTION AND IMPORTANCE}

As firstly proposed by Haliwell \& Gutteridge (1995), an antioxidant is defined as any substance able to suppress, prevent, or delay substrate oxidation under low concentrations. The mechanisms of action include Prevention, stopping radical formation chain reactions and their intermediates, Scavenger, promoting unstable molecules exhaustion cleaning up them, Reparatory, restoring native conformation 
of molecular structures through catalytic or non-catalytic ways, or Genetic, stimulating genic expression of enzymes related to cellular antioxidant capacity (Nikki 2010, Kusumawati \& Indrayanto 2013). Huang et al. (2005) stated that the chemical reactions behind antioxidant mechanisms are based on two main mechanisms of energy transfer as follows: hydrogen atom transfer (HAT) or oxidoreduction through single electron transfer (ET).

According to the aforementioned, HATbased antioxidants are those with the ability to form non-reactive compounds by single dissociation and ionization of hydrogen with unstable molecules. On the other hand, ETbased antioxidants reduce oxidized compounds interacting with molecules' functional groups (Karadag et al. 2009). Several methodologies were developed to determine the antioxidant potential of compounds using the degree of color and absorbance as a principle of measurement (Figure 2). To determine a substance's antioxidant potential the most diffused methods may request different amounts of oxidant and antioxidant and can be expressed by scavenger potential or equivalent concentration opposite to a molecule with known antioxidant capacity (Huang et al. 2005, Karadag et al. 2009).

The most used methodologies for antioxidant measurement are ABTS ${ }^{*}$ (2,2'-azinobis (3-ethylbenzothiazoline-6-sulfonic acid) cationic radical, DPPH (2,2-diphenyl-1picrylhydrazyl), $\mathrm{MO}^{6+}$ (Phosphomolydbenum Assay), ORAC (Oxygen Radical Absorbance Capacity), CUPRAC (Cupric Reducing/Antioxidant Capacity), FRAP (Ferric Reducing Antioxidant Capacity), $\mathrm{H}_{2} \mathrm{O}_{2}$ (Hydrogen Peroxide Assay), NO (Nitric Oxide Assay), $\mathrm{OH}^{\circ}$ (Hydroxyl Radical Assay), and $\mathrm{O}_{2}^{-}$(Singlet Oxygen Assay) (Kusumawati \& Indrayanto 2013). It is important to highlight the methods CUPRAC and FRAP due to several antioxidants might display a double-edged
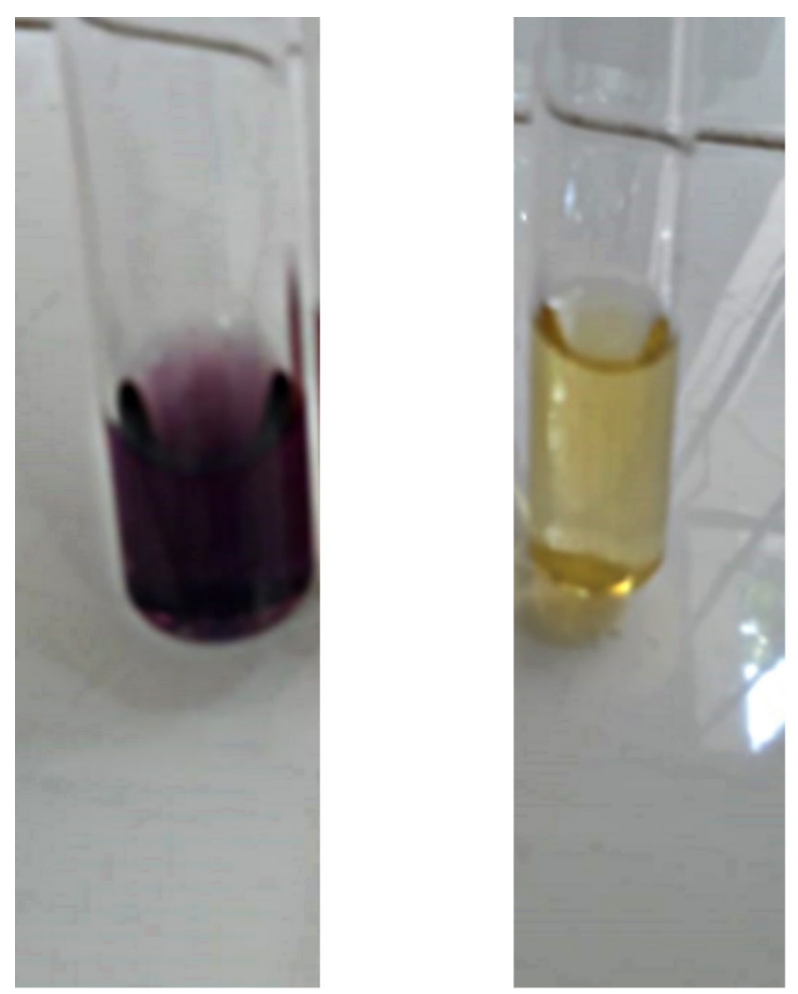

Figure 2. Antioxidant assay by DPPH (Negative control (left): DPPH + methanol; Positive control (right): DPPH + ascorbic acid).

sword role acting as both antioxidants molecules and heavy metals removing agents (Huang et al. 2005).

Antioxidant compounds may have different natures: synthetic (Figure 3), natural (Figure 4), or natural-like. The first is derived from a synthetic chemical process. The second are metabolites or products from microbes, animals, or plants. The third are those mirrored to a natural antioxidant and chemically synthesized due to molecular structure reproducibility with activity maintenance (Carocho et al. 2014). Although synthetic antioxidants are more efficient than natural, there is a lack of information about long-term usage, being also associated with allergic processes (Zaknun et al. 2012) and involvement in carcinogenesis events (Carocho et al. 2014). In contrast, natural antioxidants are preferable by consumers (Karadag et al. 2016), 
<smiles>Cc1cc(C(C)C)c(O)c(C(C)C)c1</smiles><smiles>CC(C)c1cc(O)ccc1O</smiles><smiles>COc1ccc(O)cc1C(C)C</smiles><smiles>CCOc1ccc2[nH+]ccc([As])c2c1</smiles><smiles>CCCOC(=O)c1cc(C)c(C)c(C)c1</smiles><smiles>CC(=O)CN(CCN(CC(C)=O)CC(=O)O)CC(=O)O</smiles>

Figure 3. Molecular structures of industrial synthetic antioxidants. (1) Butylated hydroxytoluene (BHT), (2) butylated hydroxyanisole (BHA), (3) propyl gallate (PG), (4) tert-butylhydroquinone (TBHQ), (5) ethoxyquin and (6) ethylenediaminetetraacetic acid (EDTA).

safer (Torres-Fuentes et al. 2015), less reactive, more compatible with human metabolism (Akbarirad et al. 2016), and without toxic limit of consumption (Lorenzo et al. 2018).

The main antioxidant application is made through incorporation into product formulations. In dermo-cosmetics, may have anti-aging action stimulating collagen production, skin integrity, elasticity, and UV light blockage (Montenegro 2014). In the food industry, antioxidants are used as conservators and oxidation delayers, especially on oil peroxidation and butter rancidity prevention (Silva \& Lidon 2016). In the pharmaceutical field, antioxidant compounds incorporated into food supplements act as nutraceuticals (Nirmala et al. 2018). Recent findings from the literature have shown antioxidants with anti-inflammatory properties (Gomes-Rochette et al. 2016) and potential candidates to help to treat cancer (Atici et al. 2018), metabolic syndrome (Gregório et al. 2016), neurodegenerative diseases (Amato et al.
2019), chronic diseases (Abdali et al. 2015), and cardiovascular diseases (Amit et al. 2015).

\section{ACTINOBACTERIA}

Actinobacteria comprise a diverse and heterogeneous group of gram-positive filamentous bacteria with highly conserved genomic content due to the predominance of $\mathrm{G}+\mathrm{C}$ genomic combination (Nouioui et al. 2018). These bacteria are mainly aerobic and mesophilic, however, some of them are able to grow under extreme conditions of oxygen absence, $\mathrm{pH}$, temperature, and salt concentration. The microscopic morphology of Actinobacteria colonies is similar to fungi, endowed of grouped thin hyphae to form a characteristic mycelium (Barka et al. 2016, Araújo-Melo et al. 2017). Macroscopically, Actinobacteria colonies may have various colors, dried aspect, crinkled appearance, and strong adherence to the surface when cultured on agar plates. The taxonomy of 


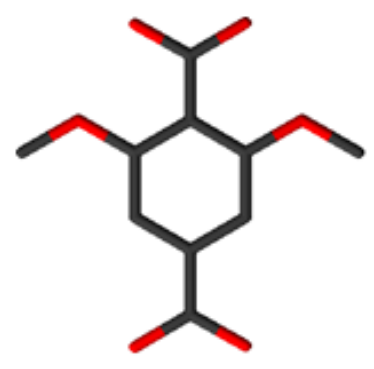

(1)

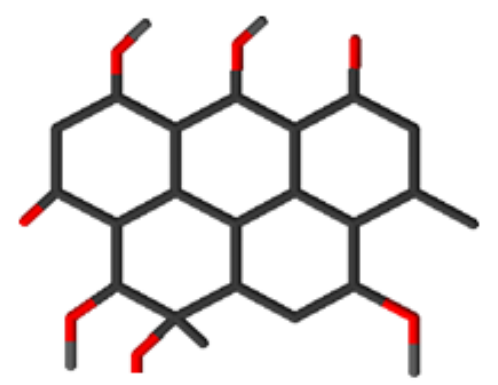

(2)
Figure 4. Tridimensional structures of antioxidant compounds produced by Actinobacteria. (1) 2,6-dimethoxyterephthalic acid, (2) 1-hydroxynorresistomycin, (3) squamocin, (4) novobiocin and (5) didodecylphthalate.

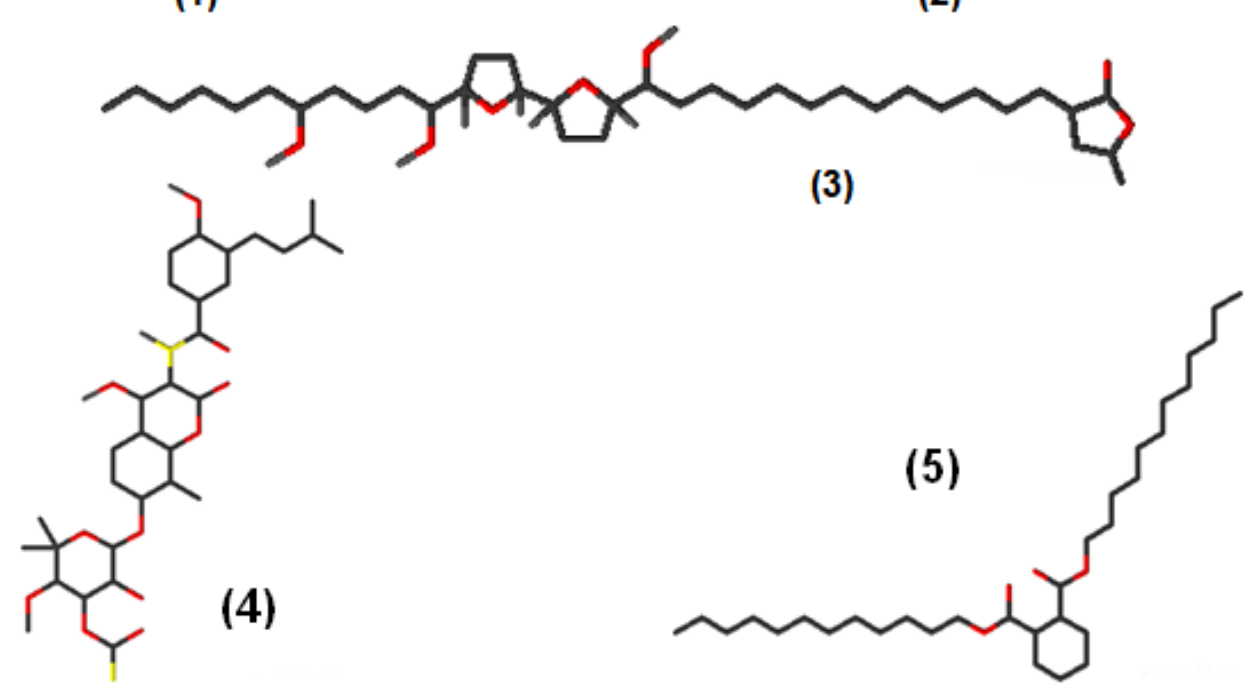

this group was based on cell wall content but currently is also focused on 16S and 23S rRNA sequences and different genes (Nouioui et al. 2018, Araújo-Melo et al. 2017).

Actinobacteria became known from the antimicrobial properties of secondary metabolites. The first Actinobacteria antibiotic discovered was streptomycin produced by Streptomyces griseus in 1943, followed by the discovery of other bioactive compounds over the years such as chemotherapeuticals, antifungals, immunomodulators, pesticides, and antihelmintics useful in medical routine, agricultural, and veterinarian fields. It is proposed that the metabolic plasticity of Actinobacteria is intrinsically related to this sortive amount of different compounds (Manteca \& Yagiu 2018). The adaptation of Actinobacteria to different environments such as glaciers, mangroves, plants, marine environments, deserts, and animals may be also another explanation for a wide range of compound production (AraújoMelo et al. 2017) (Figure 5).

The research for natural compounds remains under constant ascension being natural antioxidants a branch of this field. Many of the natural compounds produced by actinobacteria have demonstrated antioxidant properties under in vitro assays, however, there are few studies using in vivo protocols or induction models of oxidative stress. Here, we present a relevant cutting from published literature about how the Actinobacteria must be considered an important fountain of antioxidant molecules, with compounds belonging to the most different chemical classes such as phenols, alkaloids, pyrrolizidines, biphenyls, and othernon-reported compounds being its antioxidant activity mostly 


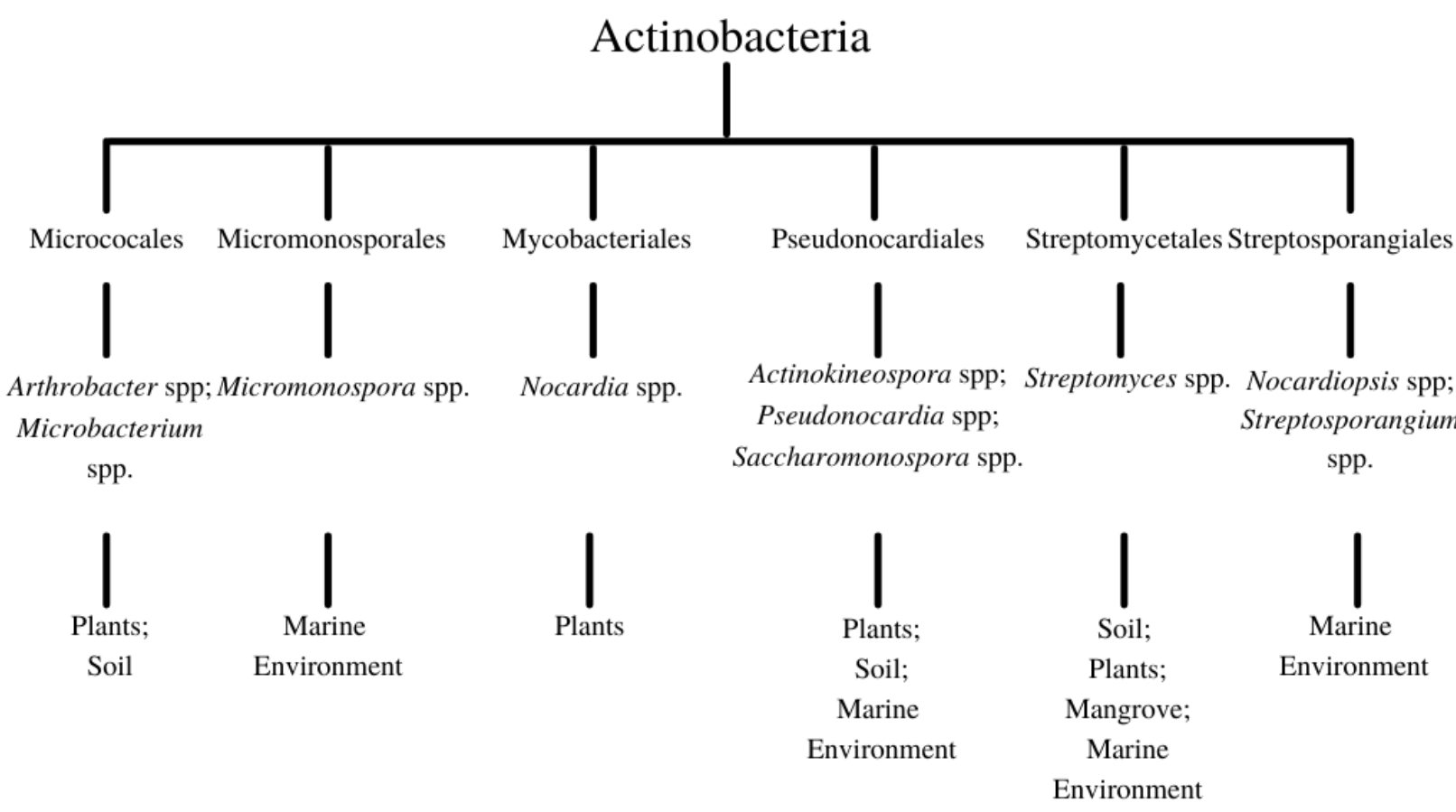

Figure 5. Different isolation environments of Actinobacteria.

related to the structural arrangements of these compounds (Tables II \& III). These antioxidant compounds from actinobacteria may be a suitable alternative to the usage of synthetic compounds in the most varied areas whereas they can stabilize strong and weak oxidants.

\section{ACTINOBACTERIA ISOLATED FROM DIFFERENT ENVIRONMENTS}

\section{Soil}

Actinobacteria are part of the soil microbiome having an important contribution to soil health. These bacteria act on organic matter decomposition, and nutrient cycling, for example (Bhatti et al. 2017). Some similar studies as the one performed by Rani et al. (2018) show up the microenvironment of plant rhizospheres as the pronest opposite to other soil regions for Actinobacteria isolation since the increased amount of nutrients around roots. Other extreme soil environments as those from desert and glaciers have also been reported as an isolation environment of Actinobacteria (Reis-Mansur et al. 2019). Thus, the soil is still considered the first choice for Actinobacteria isolation.

In spite of soil Actinobacteria exploration to find potential antimicrobial agents and other bioactive compounds, a new approach of soil Actinobacteria as a reservoir of antioxidant molecules has emerged and is ascending in the last years, turning the soil also an inexhaustible source of actinobacteria with potential for production of antioxidant molecules. Using this approach Rani et al. (2018) when evaluating Camellia senensis rhizosphere, isolated Streptomyces cellulosae TE217 where its ethyl acetate crude extract post-fermentation showed scavenger potential equal to $91.88 \%, 78.47 \%$, and $82.08 \%$ opposite to $\mathrm{ABTS}^{++}$, DPPH, and radical superoxide methods at $5 \mathrm{mg} / \mathrm{mL}$. Additionally, the phenol compounds found in the crude extract were also able to reduce molybdenum and ferrous ion being equivalent to 76.93 and $231.96 \mathrm{mg}$ of ascorbic acid/100 mg of extract dry weight, respectively. 
Table II. Phenolic and alkaloid antioxidative compounds from Actinobacteria.

\begin{tabular}{|c|c|c|c|}
\hline Chemical Classes & Producer Actinobacteria & Assay Methods & References \\
\hline \multicolumn{4}{|l|}{ Phenols } \\
\hline 4-methyl-benzoic acid & $\begin{array}{c}\text { Saccharomonospora } \\
\text { oceani VJDS-3 }\end{array}$ & DPPH, ABTS ${ }^{+\cdot}$ & (Indupalli et al. 2018) \\
\hline 2,6-dimethoxy terephthalic acid & Streptomyces sp. YIM66017 & DPPH & (Zhou et al. 2014) \\
\hline 1-hydroxy-1-norresistomycin & $\begin{array}{l}\text { Streptomyces variabilis } \\
\text { KP149559 }\end{array}$ & DPPH, $\mathrm{H}_{2} \mathrm{O}_{2}, \mathrm{OH}$, FRAP & $\begin{array}{c}\text { (Ramalingam \& Rajaram } \\
\text { 2016) }\end{array}$ \\
\hline Phenol, 2,4-bis(1,1-dimethylethyl) & Arthrobacter sp. & DPPH, FRAP, $\mathrm{MO}^{6+}$ & (Akshatha et al. 2016) \\
\hline 2,6-dimetoxyphenol & $\begin{array}{c}\text { Streptomyces } \\
\text { griseorubens NBRC12780 }\end{array}$ & DPPH & (Sengupta et al. 2015) \\
\hline $\begin{array}{c}\text { Phenol, 2,6-bis (1,1-dimethylethyl) } \\
-4-[(4-\text { hydroxy-3,5- } \\
\text { dimethylphenyl) methyl }\end{array}$ & $\begin{array}{c}\text { Streptomyces sp. strain } \\
\text { KAV2 }\end{array}$ & $\begin{array}{c}\mathrm{ABTS}^{+}, \underset{\text { FRAP }}{\text { DPPH, }} \mathrm{O}_{2}^{-}, \mathrm{MO}^{6+} \text {, } \\
\text { FRA }\end{array}$ & (Keerthana et al. 2019) \\
\hline $\begin{array}{l}\text { Phenol, 2,2'-methylenebis [6- } \\
\text { (1,1-dimethylethyl) -4-methyl }\end{array}$ & Streptomyces MUM265 & $\begin{array}{l}\mathrm{ABTS}^{+*}, \text { DPPH, } \mathrm{O}_{2}^{-}, \text {Metal } \\
\text { chelating }\end{array}$ & (Tan et al. 2019a) \\
\hline \multicolumn{4}{|l|}{ Alkaloids } \\
\hline Diazepinomicine & Micromonospora sp. RV115 & $\begin{array}{c}\text { FRAP, } \mathrm{H}_{2} \mathrm{O}_{2} \text { cell-free } \\
\text { system }\end{array}$ & (Abdelmohsen et al. 2012) \\
\hline Prodigiosin & $\begin{array}{c}\text { Streptomyces sp. WMA- } \\
\text { LM31 }\end{array}$ & $\begin{array}{c}\text { DPPH, Lipid peroxidation, } \\
\text { Protein oxidation }\end{array}$ & (Sajjad et al. 2018) \\
\hline$N$-acetyltyramine & \multirow{2}{*}{$\begin{array}{c}\text { Actinokineospora sp. } \\
\text { UTMC } 968\end{array}$} & \multirow{2}{*}{ DPPH } & \multirow{2}{*}{$\begin{array}{c}\text { (Heidari \& } \\
\text { Mohammadipanah 2018) }\end{array}$} \\
\hline$N$-acetyltryptamine & & & \\
\hline
\end{tabular}

Radhakrishnan et al. (2016) isolated Streptomyces sp. D25 from Thar Desert soil, North of India, able to produce an orangeyellow pigment with scavenger potential of 35.65\% and $96.19 \%$ when assayed by DPPH and nitric oxide at $500 \mu \mathrm{g} / \mathrm{mL}$. The work of Kaur \& Arora (2017) describes the usage of chloroform and ethyl acetate in the extraction of bioactive molecules from Actinobacteria named OS- 6 and TES-25; ethyl acetate proved the best choice. It was detected $a n I_{50}$ of $49.89 \mu \mathrm{g} / \mathrm{mL}$ and 121.51 $\mu \mathrm{g} / \mathrm{mL}$ when applied DPPH method and 2.63 $\mu \mathrm{g} / \mathrm{mL}$ and $46.61 \mu \mathrm{g} / \mathrm{mL}$ in ABTS ${ }^{++}$assay, besides that reducing power of molybdenum ion was equivalent to 83.7 and $74 \mathrm{mg}$ of ascorbic acid.

The search for antioxidant molecules from soil Actinobacteria has yielded the isolation of pure bioactive compounds such as a prodigiosin produced by Streptomyces sp. WMA-LM31 isolated from Marwart Lakki District Desert, Pakistan, was able to inhibit lipid peroxidation at $25.4 \%$ as well as protein autoxidation at $54.82 \%$ and scavenging DPPH radical at 62.5\% (Sajjad et al. 2018). Heidari \& Mohammadipanah (2018) also reported the production of two alkaloids by rare Actinobacteria Actinokineospora sp. UTMC68 isolated from the rhizospheric region on Isfahan Province, Iran, with antioxidant activities and respective $I C_{50}$ of 64.7 and $131.3 \mu \mathrm{g} / \mathrm{mL}$ when exposed to DPPH radical. The work developed by Reis-Mansur et al. (2019) describes the production of a carotenoid with possible strong antioxidant capacity from Microbacterium sp. LEMMJ01 isolated from Arctic soil. Furthermore, 
the extracts of Actinobacteria isolated from agricole soil in Egypt proved to be able to upregulate cellular antioxidant system enzymes with reduced activity in aflatoxin-treated animals (El-Nekeety et al. 2017).

\section{Plants}

The endophytic microenvironment is indicated as a promising niche for the isolation of nonrelated compounds with pharmaceutical potential. The Actinobacteria have already been isolated from herbaceous, arboreal, ornamental, and medicinal plants being frequent the isolation of rare genus as Nocardia, Pseudonocardia, and Actinomadura (Tanvir et al. 2016). The first Actinobacteria isolated from vegetal tissues were classified as belonging to the Frankia genus (Araújo-Melo et al. 2017). The knowledge about endophytic Actinobacteria has increased, however, this niche is still considered untapped or misexplored. Regarding endophytic Actinobacteria and pharmaceutical potential bioactive compounds, antitumor, antidiabetic, antimicrobial, and antioxidant properties are described. This wide potential can be associated with the stressful conditions inside vegetal tissue which Actinobacteria need to adapt to survive (Sengupta et al. 2015).

The Actinobacteria Streptomyces sp. BO-07 isolated from Boesenbergia rotunda L. radicular tissue was able to produce two compounds belonging to phenylbenzenes with $\mathrm{IC}_{50}$ equivalent to $85.84 \mu \mathrm{g} / \mathrm{mL}$ and $88.26 \mu \mathrm{g} /$ $\mathrm{mL}$ by DPPH method (Taechowisan et al. 2017). In the work developed by Akshatha et al. (2016) strains of Streptomyces globosus (JQ926176) and Arthrobacter sp. (JQ926171) were isolated from four medicinal plant stems, inflorescences, and leaves. The 21 days post-fermentation metabolic liquid extract showed reducing power of ferrous ion of $40.44 \mu \mathrm{M}$ and $52.44 \mu \mathrm{M} / \mathrm{g}$ of dry weight extract. Equivalently, Fahmy et al. (2016) observed scavenging potential varying from 62 to $85 \%$ when evaluated antioxidant potential of ethyl acetate extract from four Actinobacteria isolated from Asphodelus tenuifolius.

In a similar investigation, Tanvir et al. (2016) isolated two rare Actinobacteria named Nocardia caishijiensis and Pseudonocardia carboxydivorans from Ageratum conyzoides and Sonche oleraceus L. They reported an $I_{50}$ of 0.552 and $0.670 \mathrm{mg} / \mathrm{mL}$ by DPPH. From the evaluation of roots, leaves, and stems of Racomitrium ellipticum, Passari et al. (2017) observed that bioactive molecules present in methanolic extract from Streptomyces olivaceus BPSAC77 and Streptomyces thermocarboxydus BPSAC147 isolated from these parts scavenged $50 \%$ of DPPH at 43.2 and $75.4 \mu \mathrm{g} / \mathrm{mL}$, respectively. Curiously, a carboxyl derivative produced by Streptomyces sp. YIM66017 isolated from Alpinia oxyphylla returned an impressive $I_{50}$ of 4.16 $\mu \mathrm{g} / \mathrm{mL}$ when applied DPPH method (Zhou et al. 2014). Two acetogenins were isolated from the metabolic liquid of Streptomyces sp. VE2 recovered from Vernonia cinerea, which showed antioxidant potential with the respective $I_{50}$ 86.76 and $58.2 \mu \mathrm{g} / \mathrm{mL}$ (Taechowisan et al. 2016).

\section{Mangrove}

Brazil holds approximately $7 \%$ of global mangrove coverage, which is around $11.942 \mathrm{~km}^{2}$. Mangrove is a characteristically hypoxic, highly saline, and malodorous environment due to continuous organic matter decomposition. Mangroves are considered a diversified environment and display a pivotal role in primary productivity, vegetal stabilization, and costal line balance (Ferreira \& Lacerda 2016). The exploration of extreme environments as mangrove has been considered an escape route for the isolation of non-described compounds with potential in the pharmaceutical field once depletion of common sources as terrestrial (Sengupta et al. 2015). 
Table III. Iminosugars and other antioxidant compounds produced by Actinobacteria.

\begin{tabular}{|c|c|c|c|}
\hline Chemical Classes & Producer Actinobacteria & Assay Methods & References \\
\hline \multicolumn{4}{|l|}{ Pirrolizidines } \\
\hline $\begin{array}{l}\text { 5- (2,4-dimethyl benzyl) } \\
\text { pyrrolidine-one }\end{array}$ & Streptomyces VITSVK5 spp. & DPPH, $\mathrm{MO}^{6+}$ & (Sarauv \& Kannabiran 2012) \\
\hline $\begin{array}{c}\text { Pyrrolo [1,2-a] pyrazine-1,4-diona, } \\
\text { hexahydro }\end{array}$ & $\begin{array}{l}\text { Streptomyces mangrovisoli; } \\
\text { Streptomyces sp. MUSC14 }\end{array}$ & ABTS $^{+*}$, DPPH, SOD, Metal chelating & $\begin{array}{c}\text { (Ser et al. 2015, Kemung et al. } \\
\text { 2020) }\end{array}$ \\
\hline $\begin{array}{l}\text { Pyrrolo [1-a] pyrazine-1,4-dione, } \\
\text { hexahydro-3-(2-methylpropyl) - }\end{array}$ & Streptomyces sp. S2A & $\begin{array}{c}\text { ABTS }^{+*} \text {, DPPH, FRAP, Metal } \\
\text { chelating }\end{array}$ & (Siddharth \& Vittal 2018) \\
\hline $\begin{array}{l}\text { Pyrrolo [1,2-a] pyrazine-1,4-dione, } \\
\text { hexahydro-3- (2-methylpropyl) }\end{array}$ & Streptomyces sp. VITMK1 & DPPH, FRAP, NO• & $\begin{array}{c}\text { (Manimaram \& Kannabiran } \\
\text { 2017) }\end{array}$ \\
\hline \multicolumn{4}{|l|}{ Other Compounds } \\
\hline $\begin{array}{l}\text { 5-amino-2 (6- }(2- \\
\text { hydroxyethyl) -3- } \\
\text { oxononyl) - cyclohex-2- } \\
\text { enone }\end{array}$ & \multirow{3}{*}{$\begin{array}{l}\text { Streptomyces coelicoflavus } \\
\text { BC01 }\end{array}$} & \multirow{3}{*}{ DPPH, FRAP, $\mathrm{MO}^{6+}$} & \multirow{3}{*}{ (Rao et al. 2017) } \\
\hline $\begin{array}{c}8 \text { (aminomethyl) -7-hydroxy-1- } \\
\text { (1-hydroxy-4 - ((hydroxymethoxy) } \\
\text {-2,3-dimethyl (butyl-2-methyl- } \\
\text { dodecahydrophenanthren-9 (1H) } \\
\text {-one }\end{array}$ & & & \\
\hline $\begin{array}{c}1((E) \text {-1-ethylhex-1em-1-yl) } 2 \text { - ((E) } \\
\text {-2-ethylidenehexyl) cyclohexane- } \\
\text { 1,2-dicarboxylate }\end{array}$ & & & \\
\hline Angeloline A & Streptomyces sp. SBT345 & Cell-free system by NQO & (Cheng et al. 2016) \\
\hline $\begin{array}{l}\text { (z) -1 - ((hydroxypenta-2,4-dien-1- } \\
\text { ie) oxy) anthracene-9-10-dione }\end{array}$ & Nocardiopsis alba & DPPH, FRAP, $\mathrm{MO}^{6+}$ & (Janardhan et al. 2014) \\
\hline $\begin{array}{c}\text { 6-hydroxy-4-2 ', 3’, 4 “-tetramethyl- } \\
\text { p-terphenyl }\end{array}$ & \multirow{4}{*}{ Nocardiopsis gilva YIM90087 } & \multirow{4}{*}{$\mathrm{ABTS}^{+*}, \mathrm{DPPH}, \mathrm{O}_{2}^{-}$} & \multirow{4}{*}{ (Tian et al. 2013) } \\
\hline $\begin{array}{l}\text { 4,7-bis (4-methoxyphenyl) } \\
\text {-6-hydroxy-5-methoxybenzo [d] } \\
\text { thiazole (benzothiazole) }\end{array}$ & & & \\
\hline Novobiocin & & & \\
\hline Cyclo (L-Ile-L-Pro) & & & \\
\hline Palmitic acid, betamonoglyceride & Streptomyces globosus & DPPH, FRAP, $\mathrm{MO}^{6+}$ & (Akshatha et al. 2016) \\
\hline Actinosporine C and D & $\begin{array}{c}\text { Actinokineospora sp. strain } \\
\text { EG49 }\end{array}$ & FRAP, $\mathrm{H}_{2} \mathrm{O}_{2}$ cell-free system & (Grkovic et al. 2014) \\
\hline $\begin{array}{l}\text { 3-hydroxy-5-methoxy-3,4- } \\
\text { methylenedioxybiphenyl }\end{array}$ & \multirow{2}{*}{ Streptomyces sp. BO-07 } & \multirow{2}{*}{ DPPH } & \multirow{2}{*}{ (Taechowisan et al. 2017) } \\
\hline $\begin{array}{l}\text { 3-hydroxy-5-dimethoxy-3,4- } \\
\text { methylenedioxybiphenyl }\end{array}$ & & & \\
\hline Didodecyl phthalate & \multirow{2}{*}{ Nocardiopsis sp. VITSRTB } & \multirow{2}{*}{ DPPH, FRAP } & \multirow{2}{*}{ (Singh et al. 2013) } \\
\hline Hexacosanol acetate & & & \\
\hline 2,5-bis (1,1-dimethyethyl) & \multirow[b]{2}{*}{ Streptomyces sp. MUM212 } & \multirow{2}{*}{$\begin{array}{c}\text { ABTS }^{+*} \text {, DPPH, } \mathrm{O}_{2}^{-} \text {, Metal chelating, } \\
\text { Lipid peroxidation, } \mathrm{H}_{2} \mathrm{O}_{2} \text { cell-free } \\
\text { system }\end{array}$} & \multirow[b]{2}{*}{ (Tan et al. 2017) } \\
\hline $\begin{array}{l}\text { 2,2'-methylenebis [6- } \\
\text { (1,1-dimethylethyl) -4-methyl] }\end{array}$ & & & \\
\hline
\end{tabular}


Table III. Continuation

\begin{tabular}{|c|c|c|}
\hline Rolidecin B & Streptomyces sp. VE2 & DPPH \\
\cline { 1 - 3 } Squamocin & Streptosporangium sp. & DPPH, $\mathbf{O H}^{*}, \mathbf{O}_{2}^{-}$ \\
\hline Hexacirines & Nocardiopsis sp. SCA21 & $\mathbf{A B T S}^{+*}$, DPPH, Metal chelating \\
\hline Bis- (2-ethylhexyl) phthalate & (Siddharth \& Rai 2019) \\
\hline Saccharomonopirone A & $\begin{array}{c}\text { Sacharomonospora sp. } \\
\text { CNQ-490 }\end{array}$ & ABTS ${ }^{+*}$ DPPH \\
\hline
\end{tabular}

In this context, several authors have believed that mangrove dynamics as tidal gradient, salinity floating, radiation exposure, and other environmental conditions may be involved in the activation of metabolic pathways for the production of non-reported compounds (Tan et al. 2017).

Surprisingly, an acid-like compound was isolated from the metabolic liquid of Saccharomonospora oceani VJDS-3 and showed an excellent antioxidant activity of $73.88 \%$ and $99.74 \%$ at very low concentrations of $25 \mu \mathrm{g} /$ $\mathrm{mL}$ and $20 \mu \mathrm{g} / \mathrm{mL}$ when applied the methods of DPPH and ABTS ${ }^{++}$(Indupalli et al. 2018). The finding of Rao et al. (2017) corresponds to the molecular structure of three compounds from Streptomyces coelicoflavus BC01. These compounds showed a scavenger percentage of $63 \%, 61.92 \%$, and $52.39 \%$ in the DPPH assay. The work carried out by Tan et al. (2017) reported the scavenger potential of $35.98 \%, 67.96 \%$, and $79.23 \%$ from compounds present in the methanolic extract of Streptomyces sp. MUM292 isolated from mangrove forest soil at Kuala Selangor when assayed through DPPH, ABTS ${ }^{+}$, and radical superoxide. It is still reported the reducing power of these compounds opposite to molybdenum ion as equivalent to ascorbic acid 60.0; 59.53; and $56.66 \mu \mathrm{M} / \mathrm{mL}$. In addition to reducing power perspective, ferrous ion was also evaluated returning ascorbic acid equivalence of 67.83; 67.0 ; and $60.0 \mu \mathrm{M} / \mathrm{mL}$.

Tan et al. (2019a) believed that phenol compounds present in the methanolic extract of Streptomyces sp. MUM265 were able to inhibit dismutase superoxide in $56 \%$, act as chelating metal agents, with a percentage of $46.02 \%$ besides present a scavenger potential varying from $42.33 \%$ to $88.5 \%$ at the unique concentration of $4 \mathrm{mg} / \mathrm{mL}$. Equally, Tan et al. (2019b) observed that phenol compounds, pyrazine derivatives, and cyclic dipeptides produced by Streptomyces sp. MUM273b showed antioxidant potential with promising applications in the dermo-cosmetics field due to its potential for radiation blocking which causes keratinocytes' death. To evaluate the antioxidant capacity of Streptomyces olivaceus MSU3 ethyl acetate crude extract was assayed by many assay methods the following inhibition percentages of $62 \%, 87 \%, 32.5 \%$, 47.99\%, and $33.2 \%$ were encountered by $\mathrm{DPPH}$, total antioxidant of molybdenum ion, hydroxyl radical, and nitric oxide radical appliance (Sanjivkumar et al. 2016).

\section{Marine environment and related animals}

The marine environment is dynamic since receives influences from many outside factors. It is a diverse ecosystem fulfilled by the most different organisms. The importance of the marine environment is closely related to primary production and food withdrawal. Certainly, this environment also holds an unexplored resident microbial diversity either by symbiosis or ground housing (Beygmoradi \& Homaei 2017). The tolerance of microbes to salinity and marine stressful conditions may have headed the unprecedented exploration for new drugs 
whereas depletion of terrestrial sources and lack of novelty is a real threat (Lahoum et al. 2015). Recently, the marine environment has provided a wide variety of unheard-of compounds with promising pharmaceutical applicability, including antioxidant molecules (Beygmoradi \& Homaei 2017). In this section, it is proposed to show a small fragment from published literature about antioxidant compounds production by Actinobacteria isolated from marine sediment and related organisms.

One of the isolated antioxidant compounds from marine sources is a new chlorinated quinolone from Streptomyces sp. SBT345 isolated from a Mediterranean marine sponge, which demonstrated antioxidant potential when evaluated under a free-cell antioxidant system (Cheng et al. 2016). Ramalingam \& Rajaram (2016) isolated the strain Streptomyces variabilis KP149559 from mucus samples of Acropora formosa coral and purified a hydroxylated compound produced by this Actinobacteria with scavenger percentage varying from 75 to $82 \%$ at a concentration of $0.5 \mathrm{mg} / \mathrm{mL}$. In the work managed by Manimaran \& Kannabiran (2017) it was possible to observe that Streptomyces sp. VITMK1 produced a diketopiperazine that scavenged more than $70 \%$ of DPPH and nitric oxide radicals at $500 \mu \mathrm{g} / \mathrm{mL}$. Ravi et al. (2017) working with coastal region sediments of Rameswaram and Dhanushkodi, India, isolated the Gancidine W from chloroformic extract of Streptomyces paradoxus VITALK03 which at 1 $\mathrm{mg} / \mathrm{mL}$ exhibited antioxidant percentage of $34 \%$, $48 \%$, and $61.5 \%$ when evaluated by DPPH, ABTS ${ }^{+}$, and radical superoxide.

The crude extracts can be considered the column of antioxidant search. A derivative from pyrrolopyrazines was partially purified from ethyl acetate crude extract of the strain Streptomyces sp. S2A isolated from Mannar Gulf sediment samples by Siddharth \& Vittal
(2018) and pointed it as one of the responsible for the antioxidant activity of $56.5 \%$ and $42.4 \%$ present in the crude extract. In addition, the extract showed a metal-chelating potential of $59.98 \%$ and ferrous ion reducing power with 0.248 of absorbance. Based on the knowledge of internal microbiome existence, Gozari et al. (2018) isolated Actinobacteria strains from the stomach content of sea cucumber (Holothuria leucospilota); three strains showed an IC $C_{50}$ varying from 211 to $822 \mu \mathrm{g} / \mathrm{mL}$ when assayed by stable radical DPPH. Dholakyia et al. (2017) isolated Streptomyces variabilis RD-5 from marine soil of Khambhat Gulf Region, India, acetoethylic extract demonstrated good antioxidant properties with scavenger potential equivalent to $82.86 \%$ at DPPH, $89 \%$ of chelating activity, and inhibition potential of hydrogen peroxide higher than $85 \%$ at $5 \mathrm{mg} / \mathrm{mL}$.

\section{CONCLUSIONS}

In this review, we approached the misexplored antioxidant potential of Actinobacteria compounds. Unquestionably, antioxidants compounds have proved being essential to health, since they can restore redox cell balance and avoid cell damages caused by the excess of free radicals. Here, we showed that compounds from Actinobacteria are promising given the surprisingly antioxidant capacity of some of them as well as the discovery of non-reported antioxidant compounds by Actinobacteria. As presented, part of these compounds is strong candidates for synthetic compounds' usage replacement whereas they showed antioxidant capacity without toxicity or damage to cells. Furthermore, some of them may be applicable in the feeding industry such as some antioxidant pigments, which can perform a double role of dyeing and slowing food oxidation. Regardless 
that, we would still like to raise an observed limitation in this field. The absence of studies testing Actinobacteria antioxidant compounds using in vivo protocols, and in the same way to encourage more works to fill up this gap on the antioxidant exploration of Actinobacteria metabolites in order to assure the safety of these composites to human usage in a brief future.

\section{Acknowledgments}

The authors are grateful to CAPES (Coordenação de Aperfeiçoamento de Pessoal de Nivel Superior), CNPq (Conselho Nacional de Desenvolvimento Científico e Tecnológico) for grants and fellowship (LCBBC). Author THBO is grateful to Fundação de Amparo à Ciência e Tecnologia de Pernambuco (FACEPE) for given Scholarship (IBPG-0406-2.08/17).

\section{REFERENCES}

ABDALI D, SAMSON SE \& GROVER AK. 2015. How effective are antioxidant supplements in obesity and diabetes? Med Princ Pract 24(3): 201-215.

ABDELMOHSEN UR, SZESNY M, OTHMAN EM, SCHIRMEISTER T, GROND S, STOPPER H \& HENTSCHEL U. 2012. Antioxidant and anti-protease activities of diazepinomicin from the sponge-associated Micromonospora strain RV115. Mar Drugs 10(10): 2208-2221.

ADAMS L, FRANCO MC \& ESTEVEZ AG. 2015. Reactive nitrogen species in cellular signaling. Exp Biol Med 240(6): 711-717.

AHMADIAN E, EFTEKHARI A, SAMIEI M, DIZAJ SM \& VINKEN M. 2019. The role and therapeutic potential of connexins, pannexins and their channels in Parkinson's disease. Cell Signal 58: 111-118.

AKBARIRAD H, ARDABILI AG, KAZEMEINI SM \& KHANEGHAH AM. 2016. An overview on some of important sources of natural antioxidants. Int Food Res I 23(3): 928-933.

AKSHATHA JV, PRAKASH HS \& NALINI MS. 2016. Actinomycete endophytes from the ethnomedicinal plants of southern India: Antioxidant activity and characterization studies. J Biol Act Prod Nat 6(2): 166-172.

AMATO A, TERZO S \& MULÈ F. 2019. Natural compounds as beneficial antioxidant agents in neurodegenerative disorders: A focus on Alzheimer's disease. Antioxidants 8(12): 608.
AMIT KJ, NEELESH KM \& NITIN KS. 2015. Role of antioxidants for the treatment of cardiovascular diseases: challenges and opportunities. Curr Pharm Des 21(30): 4441-4455.

AN Y ET AL. 2019. Activation of ROS/MAPKs/NF-KB/NLRP3 and inhibition of efferocytosis in osteoclast-mediated diabetic osteoporosis. FASEB J 33(11): 12515-12527.

ANDERSSON-SJÖLAND A, KARLSSON JC \& RYDELL-TÖRMÄNEN K. 2015. ROS-induced endothelial stress contributes to pulmonary fibrosis through pericytes and wht signaling. Lab Investig 96(2): 206-217.

ARAÚJO-MELO RO, SOUZA IFAC, VICALVI-COSTA MCV, ARAÚJO JM, SENA KXRS \& COELHO LCBB. 2017. Actinobacteria: versatile microrganisms with medical and pharmaceutical application. Br Biotechnol J 15(4): 1-13.

ATICI T, ALTUN-ÇOLAK D \& ERSÖZ Ç. 2018. Protective effects of Berberis crataegina DC. (Ranunculales: Berberidaceae) extract on bleomycin-induced toxicity in fruit flies (Diptera: Drosophilidae). Rev Soc Entomol Arg 77(4): 1-8.

AULAKH GK, DUDA JA, SOLER CMG, SNEAD E \& SINGH J. 2020. Characterization of low-dose ozone-induces murine acute lung injury. Physiol Rep 8: e14463.

BARKA EA, VATSA P, SANCHEZ L, GAVEAU-VAILLANT N, CEDRIC J, KLENK HP, CLÉMENT C, OUHDOUCH Y \& VANWEZEL GP. 2016. Taxonomy, physiology, and natural products of Actinobacteria. Microbiol Mol Biol Rev 80(1): 1-43.

BEYGMORADI A \& HOMAEI A. 2017. Marine microbes as a valuable resource for brand new industrial biocatalysts. Biocatal Agric Biotechnol 11: 131-152.

BHATTI AA, HAQ S \& BHAT RA. 2017. Actinomycetes benefaction role in soil and plant health. Microb Pathog 111: 458-467.

BROWN GC \& BORUTAITE V. 2012. There is no evidence that mitochondria are the main source of reactive oxygen species in mammalian cells. Mitochondrion 12(1): 1-4.

CADENAS S. 2018. ROS and redox signaling in myocardial ischemia-reperfusion injury and cardioprotection. Free Radic Biol Med 117: 76-89.

CAROCHO M, BARREIRO MF, MORALES P \& FERREIRA ICFR. 2014. Adding molecules to food, pros and cons: A review of synthetic and natural food additives. Compr Rev Food Sci F 13: 377-399.

CHEIGNON C, TOMAS M, BONNENFONT-ROUSSELOT D, FALLER P, HUREAU C \& COLLIN F. 2018. Oxidative stress and the amyloid-beta peptide in Alzheimer's disease. Redox Biol 14: $450-464$.

CHENG C, OTHMAN EM, REIMER A, GRÜNE M, KOZJAK-PAULOVIC V, STOPPER H, HENTSCHEL U \& ABDELMOHSEN UR. 2016. 
Angeloline $A$, new antioxidant and antichlamydial quinolone from the marine sponge-derived bacterium Streptomyces sp. SBT345. Tetrahedron Lett 57(25): 2786-2789.

DEY SD, MAGUNDER D, SIDOR A, FOSTER DBO \& ROURKE B. 2018. Mitochondrial ROS drive sudden cardiac death and chronic proteome remodeling in heart failure novelty and significance. Circ Res 123(3): 356-371.

DHOLAKYIA RN, KUMAR R, MISHRA A, MODY KH \& JHA B. 2017. Antibacterial and antioxidant activities of novel Actinobacteria strain isolated from Gulf of Khamblat, Gurajat. Front Microbiol 8 Article 2420.

DIEBOLD L \& CHANDEL NS. 2016. Mitochondrial ROS regulation of proliferating cells. Free Radic Biol Med 100: 86-93.

DRIVER AS, KODOWANTI PRS \& MUNDY WR. 2000. Age-related changes in reactive oxygen species production in rat brain homogenates. Neurotoxicol Teratol 22(2): 175-181.

EL-NEKEETY AA, SALMAN AS, HATHOUT AS, SABRY BA, ABDELAZIEM SH, HASSAN NS \& ABDEL-WAHHAB MA. 2017. Evaluation of the bioactive extract of actinomycetes isolated from the Egyptian environment against aflatoxin b1-induced cytoxicity, genotoxicity and oxidative stress in the liver of rats. Food Chem Toxicol 105: 241-255.

ENGIN A. 2017. The pathogenesis of obesity-associated adipose tissue inflammation. Adv Exp Med Biol, p. 221-245.

FAHMY DM, SIDKEY N, ELKAWAGA M \& ZAID DS. 2016. Antimicrobial and antioxidant potentials of endophytic actinomycetes isolated from leaves of Asphodelus tenuifolius (CAV.) (MARSA MATROUH, EGYPT). Egypt J Desert Res 66(2): 373-386.

FERREIRA AC \& LACERDA LD. 2016. Degradation and conservation of Brazilian mangroves, status and perspectives. Ocean Coast Manag 125: 38-46.

FIONDA C, ABRUZESSE MP, SANTONI A \& CIPPITELLI M. 2016. Immunoregulatory and effector activities of nitric oxide and reactive nitrogen species in Cancer. Curr Med Chem 23(24): 2618-2636.

FU J, SHAO Y, WANG L \& ZHU Y. 2015. Lysosome-controlled efficient ROS overproduction against cancer cells with a high pH-responsive catalytic nanosystem. Nanoscale 7: $7275-7283$.

FURUKAWA S, FUJITA T, SHIMABUKURO M, IWAKI M, YAMADA $Y$, NAKAJIMA Y, NAKAYAMA O, MAKISHIMA M, MATSUDA M \& SHIMOMURA I. 2004. Increased oxidative stress in obesity and its impact on metabolic syndrome. J Clin Invest 114(12): 1752-1761.
GAO C, GUO Z, LU X, CHEN H, LIU L, YU Z \& CHEN Y. 2018. Hexaricins, pradimicin-like polyketides from a marine sediment derived Streptosporangium sp. and their antioxidant effects. J Nat Prod 81: 2061-2074.

GARCÍA-RUIZ C \& FERNANDÉZ-CHECA JC. 2018. Mitochondrial Oxidative Stress and Antioxidants Balance in Fatty Liver Disease. Hepatol Communi 2(12): 1425-1439.

GOEL R \& CHAUDHARY R. 2020. Effect of daidzein on Parkinson disease induced by reserpine in rats. Braz J Pharm Sci 56: 1-7.

GOMES-ROCHETTE NF, VASCONCELOS MS, NABAVI SM, MOTA EF, NUNES-PINHEIRO DCS, DAGLIA M \& DE MELO DF. 2016. Fruit as potent natural antioxidants and their biological effects. Curr Pharm Biotechnol 17: 986-993.

GOZARI M, BAHADOR N, JASSBI AR, MORTAZAVI MS \& EFTEKHAR E. 2018. Antioxidant and cytotoxic activities of metabolites produced by a new marine Streptomyces sp. isolated from the sea cucumber Holothuria leucospilota. Iran J Fish Sci 17(2): 413-426.

GREGÓRIO BM, SOUZA DB, NASCIMENTO FAM, MATTA L \& FERNANDES-SANTOS C. 2016. The potential role of antioxidants in metabolic syndrome. Curr Pharma Des 22(7): 859-869.

GRKOVIC T, ABDELMOHSEN UR, OTHMAN EM, STOPPER H, EDRADAEBEL R, HENTSCHEL U \& QUIN RJ. 2014. Two new antioxidant actinosporin analogues from the calcium alginate beads culture of sponge-associated Actinokineospora sp. strain EG49. Bioorganic Med Chem Lett 24(21): 5089-5092.

GUO J, ZHAO X, LI Y, LI G \& LIU X. 2018a. Damage to dopaminergic neurons by oxidative stress in Parkinson's disease. Int J Mol Med 41: 1817-1825.

GUO Y, ZHUANG X, HUANG Z, ZOU J, YANG D, HU X, DU Z, WANG L \& LIAO X. 2018b. Klotho protects the heart from hyperglycemia-induced injury by inactivating ROS and NF-KB-mediated inflammation both in vitro and in vivo. BBA-Mol Basis Dis 1864(1): 238-251.

HA HL \& YU DY. 2010. HBX-induced reactive oxygen species activates hepatocellular carcinogenesis via dysregulation of PTEN/Akt pathway. World J Gastroenterol 16(39): 4932-4937.

HALIWELL B \& GUTTERIDGE JM. 1995. The definition and measurement of antioxidants in biological systems. Free Radic Biol Med 18(1): 125-126.

HEIDARI B \& MOHAMMADIPANAH F. 2018. Isolation and identification of two alkaloid structures with radical scavenging activity from Actinokineospora sp. UTMC 968, a new promising source of alkaloid compounds. Mol Biol Rep 45: 2325-2332. 
HENDRIJANTINI N, ROSTINY KA, ARI MDA, SITALAKSMI RM, HAPSARI PD, ARIEF VV \& SATI PYI. 2019. Molecular triad RANK/ RANKL/ OPG in mandible and femur of wistar rats (Rattus norvegicus) with type 2 diabetes mellitus. Recent Adv Biol Med 5 Article ID 959614.

HENKLER F, BRINKMANN J \& LUCH A. 2010.The role of oxidative stress in carcinogenesis induced by metals and xenobiotics. Cancers 2(2): 376-396.

HU T, SUN H, DENG WY, HUANG WQ \& LIU Q. 2018. Augmenter of liver regeneration protects against acetaminopheninduced acute liver injury in mice by promoting autophagy. Shock 52(2): 274-283.

HUANG D, OU B \& PRIOR RL. 2005. The chemistry behind antioxidant capacity assays. J Agric Food Chem 53(6): 1841-1856.

HUANG $X$, HUANG $X$, GONG Y, XIAO H, MCCLEMENTS DJ \& HU K. 2016. Enhancement of curcumin water dispersibility and antioxidant activity using core-shell proteinpolysaccharide nanoparticles. Food Res Int 87: 1-9.

HWANG Y, KIM JC \& TAE G. 2019. Significantly enhanced recovery of acute liver failure by liver targeted delivery of stem cells via heparin functionalization. Biomaterials 209: 67-78.

INDUPALLI M, MUVVA V, MANGAMURI U, MUNAGANTI RK \& NARAGANI K. 2018. Bioactive compounds from mangrove derived rare actinobacterium Saccharomonospora occeani VIDS-3. 3 Biotech 8 Article number 103.

JANARDHAN A, KUMAR AP, VISWANATH B, SAIGOPAL DVR \& NARASHIMA G. 2014. Production of bioactive compounds by actinomycetes and their antioxidant properties. Biotechnol Res Int Article ID217030.

KARADAG A, HERMUND DB, JENSEN LHS, ANDERSEN U, JÓNSDÓTTIR R, KRISTINSSON HG, ALASALVAR C \& JACOBSEN C. 2016. Oxidative stability and microstructure of $5 \%$ fishoil-enriched granola bars added natural antioxidants derived from brown alga Fucus vesiculosus. Eur J Lipid Sci Technol 119(4): 1500578.

KARADAG A, OZCELIK B \& SANER S. 2009. Review of methods to determine antioxidant capacities. Food Anal Methods 2(1): 41-60.

KAUR J \& ARORA S. 2017. Actinobacteria from soil as potential free radical scavengers. Malays J Microbiol 13(3): 217-227.

KEERTHANA S, ABILASHA R, SARASWATHI K \& ARUMUGAM P. 2019. Antioxidant and antibacterial products evaluation from terrestrial Streptomyces sp. strain KAV2 isolated from rhizosphere regions of Piper betle. J Drug Deliv Ther 9(14-A): 26-37.
KELLNER M, NOONEPALLE S, LU Q, SRIVASTAVA A, ZEMSKOV E \& BLACK SM. 2017. ROS signaling in the pathogenesis of acute lung injury (ALI) and acute respiratory distress syndrome (ARDS). In: Wang YX (Ed) Pulmonary vasculature redox signaling in health and disease. Adv Exp Med Biol, Springer, Camb, p. 105-137.

KEMUNG HM, TAN LTH, CHAN KG, SER HL, LAW JWF, LEE LH \& GOH BH. 2020. Antioxidant activities of Streptomyces sp. strain MUSC 14 from mangrove forest soil in Malaysia. Biomed Res Int Article ID6402607.

KHOJAH HM, AHMED S, ABDEL-RAHMAN MS \& HAMZA AB. 2016. Reactive oxygen and nitrogen species in patients with rheumatoid arthritis as potential biomarkers for disease activity and the role of antioxidants. Free Radic Biol Med 97: 285-291.

KIM HY ET AL. 2018. Sicyos angulatus ameliorates acute liver injury by inhibiting oxidative stress via upregulation of anti-oxidant enzymes. Redox Rep 23(1): 206-212.

KOVAC S, ANGELOVA PR, HOLMSTRÖM KM, ZHANG Y, DINKOVAKOSTOVA AT \& ABRAMOV AY. 2015. Nrf2 regulates ROS production by mitochondria and NADPH oxidase. Biochim Biophys Acta Gen Subj 1850(4): 794-801.

KUSUMAWATI I \& INDRAYANTO G. 2013. Natural antioxidants in cosmetics. Stud Nat Prod Chem 40: 485-505.

LAHOUM A, BOURAS N, MATHIEU F, SCHUMANN P, SPRÖER C, KLENK HP \& SABAOU N. 2015. Actinomadura algeriensis sp. nov., an actinobacterium isolated from Saharan soil. Antonie van Leeuwenhoek 109(1): 159-165.

LI Y ET AL. 2016. Potential hepatoprotective effects of fullerenol nanoparticles on alcohol-induced oxidative stress by ROS. RSC Adv 6(37): 31122-31130.

LIU D, WU M, LU Y, XIAN T, WANG Y, HUANG B, ZHENG G \& HUANG Q. 2017. Protective effects of 6 -gingerol on vascular endothelial cell injury induced by high glucose via activation of PI3K-AKT-eNOS pathway in human umbilical vein endothelial cells. Biomed Pharmacother 93: 788-795.

LIU Z, WANG X, LI L, WEI G \& ZHAO M. 2020. Hydrogen sulfide protects against paraquat-induced acute liver injury in rats by regulating oxidative stress mitochondrial function and inflammation. Oxid Med Cell Longev Article ID 6325378.

LORENZO JM, PATEIRO M, DOMÍNGUEZ R, BARBA FJ, PUTNIK P, KOVAČEVIĆ DB, SHPIGELMAN A, GRANATO D \& FRANCO D. 2018. Berries extracts as natural antioxidants in meat products: A review. Food Res Int 106: 1095-1104.

LU L, LU Q, CHEN W, LI J, LI C \& ZHENG Z. 2018. Vitamin D3 protects against diabetic retinopathy by inhibiting high-glucose-induced activation of the ROS/TXNIP/ 
NLRP3 inflammasome pathway. J Diabetes Res Article ID 8193523.

MANIMARAM M \& KANNABIRAN K. 2017. Marine Streptomyces sp. VITMK1 derived pyrrolo [1,2-a] pyrazine-1,4-dione, hexahydro-3-(2-methylpropyl) and its free radical scavenging activity. The Open Bioactive Compounds Journal 5: 23-30.

MANTECA A \& YAGIU P. 2018. Streptomyces differentiation in liquid cultures as a trigger of secondary metabolites. Antibiotics 7(2): 41.

MARSEGLIA L, MANTI S, D'ANGELO G, NICOTERA A, PARISI E, DI ROSA G, GITTO E \& ARRIGO T. 2014. Oxidative stress in obesity: A critical component in human diseases. Int J Mol Sci 16(1): 378-400.

MARTÍNEZ MC \& ANDRIANTSITOHAINA R. Reactive nitrogen species: molecular mechanisms and potential significance in health and disease. 2009. Antioxid Redox Signal 11(3): 669-702.

MILLER WP, TORO AL, BARBER AJ \& DENNIS MD. 2019. REDD1 Activates a ROS-generating feedback loop in the retina of diabetic mice. Invest Ophth Vis Sci 60(6): 2369-2379.

MONTENEGRO L. 2014. Nanocarriers for skin delivery of cosmetic antioxidants. J Pharm Pharmacogn Res 2(4): 73-92.

MOURIER A \& LARSSON NG. 2011. Tracing the trail of protons through complex I of the mitochondrial respiratory chain. PLoS Biol 9(8): e1001129.

NAYERNIA Z, JAQUET V \& KRAUSE KH. 2014. New insights on Nox enzymes in the central nervous system. Antioxid Redox Sign 20(17): 2815-2837.

NEWSHOLME P, CRUZAT VF, KEANE KN, CARLESSI R \& BITTENCOURT $\mathrm{PIH}$. 2016. Molecular mechanisms of ROS production and oxidative stress in diabetes. Biochem J 473(24): 4527-4550.

NGUYEN NH, TRAN G \& NGUYEN CT. 2020. Anti-oxidative effects of superoxide dismutase 3 on inflammatory diseases. J Mol Med 98: 59-69.

NIKKI E. Assessment antioxidant capacity in vitro and in vivo. 2010. Free Radic Biol Med 49: 503-515.

NIRMALA C, BISHT MS, BAJWA HK \& SANTOSH O. 2018. Bamboo: A rich source of natural antioxidants and its applications in the food and pharmaceutical industry. Trends Food Sci Tech 77: 91-99.

NOUIOUI I, CARRO L, GARCÍA-LÓPEZ M, MUER-KOLTHOFF IP, WOYKE T, KYRPIDES NC, PUKALL R, KLENK HP, GOODFELLOW M \& GÖKER M. 2018. Genome-based taxonomic classification of the phylum Actinobacteria. Front Microbiol 9: 2007.
ODINOKOVA I, BABURINA Y, KRUGLOV A, FADEEVA I, ZVYAGINA A, SOTNIKOVA L, AKATOV V \& KRESTININA O. 2018. Effect of melatonin on rat heart mitochondria in acute heart failure in aged rats. Int J Mol Sci 19(6): 1555.

PANTH N, PAUDEL KR \& PARAJULI K. 2016. Reactive oxygen species: A key hallmark of cardiovascular disease. Adv Med Article ID 9152732.

PASSARI AK, MISHRA VK, SINGH G, SINGH P, KUMAR B, GUPTA VK, SARMA RK, SAIKIA R, DONOVAN AO \& SINGH BP. 2017. Insights into the functionality of endophytic actinobacteria with a focus on their biosynthetic potential and secondary metabolites production. Sci Rep 7 Article number 11809.

PHANIENDRA A, JESTADI DB \& PERIYASAMY L. 2015. Free radicals: properties, sources, targets, and their implication in various diseases. Indian J Clin Biochem 30(1): 11-26.

PINHEIRO LC \& OLIVEIRA-PAULA GH. 2019. Sources and effects of oxidative stress in hypertension. Curr Hypertens Rev 15: 1-13.

PROPAC P, JORNOVA K, SIMUNKOVA M, KOLLAR V, RHODES CJ \& VALKO M. 2017. Targeting free radicals in oxidative stress - Related human diseases. Trends Pharmacol Sci 38(7): 592-607.

QIN L, JIA P, ZHANG Z \& ZHANG S. 2015. ROS-p53-cyclophilin-D signaling mediates salinomycin-induced glioma cell necrosis. J Exp Clin Cancer Res 34 Article number 57.

RADHAKRISHNAN M, GOPIKRISHNAN V, VIJAYALAKSHMI G \& KUMAR V. 2016. In vitro antioxidant activity and antimicrobial activity against biofilm forming bacteria by the pigment from desert soil Streptomyces sp. D25. J Appl Pharm Sci (6): 148-150.

RAMALINGAM V \& RAJARAM R. 2016. Antioxidant activity of 1-hydroxy-1-norresistomicin derived from Streptomyces variabilis KP149559 and evaluation of its toxicity against zebra fish Danio rerio. RSC Adv 6(20): 16615-16623.

RANCAN L, PAREDES S, GARCÍA C, GONZÁLEZ P, RODRÍGUEZBOBADA C, CALVO-SOTO M, HYANCINTHE B, VARA E \& TRESGUERRES J. 2018. Comparison of the effect of melatonin treatment before and after brain ischemic injury in the inflammatory and apoptotic response in aged rats. Int J Mol Sci 19(7): 2097.

RANI R, ARORA S, KAUR J \& MANHAS RK. 2018. Phenolic compounds as antioxidants and chemopreventive drugs from Streptomyces cellulosae strain TES17 isolated from rhizosphere of Camellia sinensis. BMC Complement Altern Med 18(1): Article number 82.

RAO RKV, MANI P, SATYANARAYANA B \& RAO RT. 2017. Purification and strutuctural elucidation of three bioactive 
compounds isolated from Streptomyces coelicoflavus BC01 and their biological activity. 3 Biotech 7(1): 24.

RAVI L, RAGUNATHAN A \& KRISHNAN K. 2017. Antidiabetic and antioxidant potential of gancidin $W$ from Streptomyces paradoxus VITALK03. The Open Bioactive Compounds Journal 5: 31-42.

REDZA-DUTORDOIR M \& AVERILL-BATES DA. 2016. Activation of apoptosis signalling pathways by reactive oxygen species. Biochim Biophys Acta Mol Cell Res 1863(12): 2977-2992.

REIS-MANSUR MCPP ET AL. 2019. Carotenoids from UVresistant antarctic Microbacterium sp. LEMMJ01. Sci Rep 9 Article number 9554.

SAJJAD W, AHMAD S, AZIZ I, AZAM SS, HASAN F \& SHAH AA. 2018. Antiproliferative, antioxidant and binding mechanism analysis of prodigiosin from newly isolated radioresistant Streptomyces sp. strain WMA-LM31. Mol Biol Rep 45: 1787-1798.

SANJIVKUMAR M, BABU DR, SUGANYA AM, SILAMBARASAN T, BALAGURUNATHAN R \& IMMANUEL G. 2016. Investigation on pharmacological activities of secondoray metabolite extracted from a mangrove associated actinobacteria Streptomyces olivaceus (MSU3). Biocatal Agric Biotechnol 6: 82-90.

SARAUV K \& KANNABIRAN K. 2012. Cytotoxic and antioxidant activity of 5-(2,4-dimethylbenzyl) pyrrolidin-2-one extracted from marine Streptomyces spp. VITSVK5. Saudi J Biol Sci 19: 81-86.

SENGUPTA S, PRAMANIK A, GHOSH A \& BHATTACHARYYA M. 2015. Antimicrobial activities of actinomycetes isolated from unexplored regions of Sundarbans mangrove ecosystem. BMC Microbiol 15 Article number 170.

SER HL, PALANISAMY UD, YIN WF, MALEK SNA, CHAN KG, GOH BH \& LEE LH. 2015. Presence of antioxidative agent, pyrrolo [1,2-a] pyrazine-1,4-dione, hexahydro- in newly isolated Streptomyces mangrovisoli sp. nov. Front Microbiol 6: 854.

SHI Q, LEI Z, CHENG G, LI D, WANG Q, LUO S, YANG H \& JIA H. 2018. Mitochondrial ROS activate interleukin-1及 expression in allergic rhinitis. Oncol Lett 16: 33193-33200.

SIDDHARTH S \& RAI VR. 2019. Isolation and characterization of bioactive compounds with antibacterial, antioxidant and enzyme inhibitory activities from marine-derived rare actinobacteria Nocardiopsis sp. SCA21. Microb Pathog 137: 103775.

SIDDHARTH S \& VITTAL RR. 2018. Evaluation of antimicrobial, enzyme inhibitory, antioxidant and cytotoxic activities of partially purified volatile metabolites of marine Streptomyces sp. S2A. Microorganisms 6(3): 72.

SILVA MM \& LIDON FC. 2016. An overview on applications and side effects of antioxidant food additives. Emir J Food Agric 28(12): 823-832.

SIMPLICIO JA, DO VALE GT, GONZAGA NA, LEITE LN, HIPÓLITO UV, PEREIRA CA, TOSTES RC \& TIRAPELLI CR. 2016. Reactive oxygen species derived from NAD(P)H oxidase play a role on ethanol-induced hypertension and endothelial dysfunction in rat resistance arteries. J Physiol Biochem 73(1): 5-16.

SINDHU S, AKHTER N, KOCHUMON S, THOMAS R, WILSON A, SHENOUDA S, TUOMILEHTO I \& AHMAD R. 2018. Increased expression of the innate immune receptor TLR10 in obesity and type-2 diabetes: Association with ROSmediated oxidative stress. Cell Physiol Biochem 45(2): 572-590.

SINGH S, PRADHAN N, KUMARI R \& RAO B. 2013. Evaluation of antioxidant and cytotoxic activity of bioactive compounds extracted from Nocardiopsis VITSRTB. Int J Appl Eng Res 8(9): 2203-2208.

SOKOLOWSKA M, QUESNIAUX VFJ, AKDIS CA, CHUNG KF, RYFFEL B \& TOGBE D. 2019. Acute respiratory barrier disruption by ozone exposure in mice. Front Immunol 10: 2169.

SRINIVAS US, TAN BWQ, VELLAYAPPAN BA \& JEYASEKHARAN AD. 2019. ROS and the DNA damage response in cancer. Redox Biol 25: 101084.

TAECHOWISAN T, SINGTOTONG C \& PHUTDHAWONG WS. 2016. Antibacterial and Antioxidant Activities of Acetogenins from Streptomyces sp. VE2., an endophytic in Vernonia cinerea (L.) Less. J Appl Pharm Sci 6(8): 67-72.

TAECHOWISAN T, CHAISAENG S \& PHUTDHAWONG WS. 2017. Antibacterial, antioxidant and anticancer activites of biphenyls from Streptomyces sp. BO-07 and endophyte in Boesenbergia rotunda (L.) Mansf A. Food Agr Immunol 28(6): 1330-1346.

TAN LTH, CHAN KC, PUSPARAJAH P, YIN WF, KHAN TM, LEE LH \& GOH BH. 2019a. Mangrove derived Streptomyces sp. MUM265 as a potential source of antioxidant and anticoloncancer agents. BMC Microbiol 19 Article number 38.

TAN LTH, CHAN KG, KHAN TM, BUKHARI SI, SAOKAEW S, DUANGJAIN A, PUSPARAJAH P, LEE LH \& GOH BH. 2017. Streptomyces sp. MUM212 as a source of antioxidants with radical scavenging and metal chelating properties. Front Pharmacol 8: 276.

TAN LTH, MAHENDRA CK, YOW YY, CHAN KG, KHAN TM, LEE LH \& GOH BH. 2019b. Streptomyces sp. MUM237b: A 
mangrove-derived potential source for antioxidant and UVB radiation protectants. Microbiologyopen 8(10): e859.

TANVIR R, SAJID J, HASMAIN S, KULIK A \& GROND S. 2016. Rare actinomycetes Nocardia caishiiensis and Pseudonocardia carboxydivorans as endophytes their bioactivity and metabolites evaluation. Microbiol Res 185: 22-35.

THUY LE TT, THUY TTV, HAI H \& KAWADA N. 2017. Role of oxidative and nitrosative stress in hepatic fibrosis. Liver Pathophysiol, p. 213-224.

TIAN SZ, PU X, LUO G, ZHAO LX, XU LH, LI WJ \& LUO Y. 2013. Isolation and characterization of new $p$-terphenyls with antifungal, antibacterial, and antioxidant activities from halophilic actinomycete Nocardiopsis gilva YIM90087. J Agric Food Chem 61(12): 3006-3012.

TIAN Z, CHEN Y, YAO N, HU C, WU Y, GUO D, LIU J, YANG Y, CHEN T, ZHAO Y \& HE Y. 2018. Role of mitophagy regulation by ROS in hepatic stellate cells during acute liver failure. Am J Physiol Gastrointest Liver Physiol 315: G374-G384.

TOPAL A, ALAK G, ALTUN S, EROL HS \& ATAMANALP $M$. 2017. Evaluation of 8-hydroxy-2-deoxyguanosine and NFkB activation, oxidative stress response, acetylcholinesterase activity, and histopathological changes in rainbow trout brain exposed to linuron. Environ Toxicol Pharmacol 49: 14-20.

TORRES-FUENTES C, CONTRERAS MDM, RECIO I, ALAIZ M \& VIOQUE J. 2015. Identification and characterization of antioxidant peptides from chickpea protein hydrolysates. Food Chem 180: 194-202.

TRIPATHI DN \& WALKER CL. 2016. The peroxisome as a cell signaling organelle. Curr Opin Cell Biol 39: 109-112.

TURILLAZZI E ET AL. 2017. Myocardial oxidative damage is induced by cardiac Fas-dependent and mitochondriadependent apoptotic pathways in human cocainerelated overdose. Sci Rep 7 Article number 44262.

WANG L, XU J, LIU H, LI J \& HAO H. 2019. PM2.5 inhibits SOD1 expression by up-regulating microRNA-206 and promotes ROS accumulation and disease progression in asthmatic mice. Int Immunopharmacol 76: 105871.

WANG L, YIN YL, LIU XZ, SHEN P, ZHENG YG, LAN XR, LU CB \& WANG JZ. 2020. Current understanding of metal ions in the pathogenesis of Alzheimer's disease. Transl Neurodegener 9: 10.

WANG M \& KAUFMAN RJ. 2016. Protein misfolding in the endoplasmic reticulum as a conduit to human disease. Nature 529: 326-335.
WANG X, LIU M, ZHANG C, LI S, YANG Q, ZHANG J, GONG Z, HAN J \& JIA L. 2018. Antioxidant activity and protective effects of enzyme-extracted molecules. Molecules 23(2): 481.

XU F ET AL. 2019a. Protective effects and mechanisms of vaccarin on vascular endothelial dysfunction in diabetic angiopathy. Int J Mol Sci 20: 4587.

XU M ET AL. 2019b. Mitochondrial ROS and NLRP3 inflammasome in acute ozone-induced murine model of airway inflammation and bronchial hyperresponsiveness. Free Radic Res 53(7): 780-790.

YAN Q, HE B, HAO G, LIU Z, TANG J, FU Q \& JIANG CX. 2019. KLF9 aggravates ischemic injury in cardiomyocytes through augmenting oxidative stress. Life Sci 233: 116641.

YANG L, LIN Z, WANG Y, LI C, XU W, LI Q, YAO W, SON Z \& LIU G. 2017b. Nickle (II) ions exacerbate bleomycin-induced pulmonary inflammation and fibrosis by activating the ROS/Akt signaling pathway. Environ Sci Pollut Res 25(5): 4406-4418.

YANG L, WANG WC, LUNG SCC, SUN Z, CHEN C, CHEN JK, ZOU Q, LIN YH \& LIN CH. 2017a. Polycyclic aromatic hydrocarbons are associated with increased risk of chronic obstructive pulmonary disease during haze events in China. Sci Total Environ 574: 1649-1658.

YIM CY ET AL. 2017. Saccharomonopyrones A-C, new a-pyrones from a marine sediment-derived bacterium Saccharomonospora sp. CNQ-490. Mar Drugs 15(8): 239.

YOO S ET AL. 2018. Oxidative stress creates a unique CaMKII-mediated substrate for atrial fibrilation in heart failure. JCI Insight 3(21): e120728.

ZAKNUN D, SCHROECKSNADEL S, KURZ K \& FUCHS D. 2012. Potential role of antioxidant food supplements, preservatives and colorants in the pathogenesis of allergy and asthma. Int Arch Allergy Immunol 157(2): $113-124$

ZHANG H ET AL. 2018b. Gypenosides improve diabetic cardiomyopathy by inhibiting ROS-mediated NLRP3 inflammasome activation. J Cell Mol Med 22(9): 4437-4448.

ZHANG S, EITAN E, WU TY \& MATTSON MP. 2018a. Intercellular transfer of pathogenic $\alpha$-synuclein by extracellular vesicles is induced by the lipid peroxidation product 4-hydroxynonenal. Neurobiol Aging 61: 52-65.

ZHOU H, YANG Y, PENG T, LI W, ZHAO L, XU L \& DING Z. 2014. Metabolites of Streptomyces sp., an endophytic actinomycete from Alpinia oxyphylla. Nat Prod Res 28 (4): 265-267.

ZHOU Y, ZHEN M, MA H, LI J, SHU C \& WANG C. 2018. Inhalable gadofullerenol/[70] fullerenol as high-efficiency ROS 
scavengers for pulmonary fibrosis therapy. NanomedNanotechnol 14(4): 1361-1369.

ZUKOWSKI P, MACIEJCZYK M \& WASZKIEL D. 2018. Sources of free radicals and oxidative stress in the oral cavity. Arch Oral Biol 92: 8-17.

\section{How to cite}

DE OLIVEIRA THB, DE GUSMÃO NB, DA SILVA LAO \& COELHO LCBB. 2021. Free Radicals and Actinobacteria as a Misexplored Goldmine of Antioxidant Compounds. An Acad Bras Cienc 93: e20201925. DOI 10.1590/0001-3765202120201925.

Manuscript received on December 15, 2020;

accepted for publication on March 23, 2021

THALES HENRIQUE B. DE OLIVEIRA ${ }^{1}$

https://orcid.org/0000-0003-0296-7373

NORMA B. DE GUSMÃO

https://orcid.org/0000-0001-6700-9876

\section{LEONOR A.O. DA SILVA}

https://orcid.org/0000-0003-3916-1453

\section{LUANA C.B.B. COELHO 1}

https://orcid.org/0000-0002-1013-0023

${ }^{1}$ Universidade Federal de Pernambuco, Departamento de Bioquímica, Centro de Biociências, Avenida Professor Moraes Rego, s/n, Cidade Universitária, 50670-420 Recife, PE, Brazil
${ }^{2}$ Universidade Federal de Pernambuco, Departamento de Antibióticos, Centro de Biociências, Avenida dos Economistas, s/n, Cidade Universitária, 52171-011 Recife, PE, Brazil

${ }^{3}$ Universidade Federal da Paraíba, Departamento de Biologia Molecular, Centro de Ciências Exatas e da Natureza, Conjunto Presidente Castelo Branco III, 58033-455 João Pessoa, PB, Brazil

\section{Correspondence to: Luana Cassandra \\ Breitenbach Barroso Coelho \\ E-mail:Lcbbcoelho@gmail.com}

\section{Author contributions}

This work was carried out through collaboration among all authors. Author THBO and LCBBC managed the literature searches and wrote the manuscript. Authors NBG and LAOS participated in revision of this article and contributed with comments. Authors THBO and LCBBC performed revision of manuscript and English translation. Authors LAOS and LCBBC designed, supervised and managed the study performed. All authors read and approved the final manuscript.

\section{(cc) BY}

